\title{
EL SISTEMA REFERENCIAL EN ESPAÑOL ANTIGUO: LEISMO, LAÍSMO Y LOÍSMO
}

La confusión en el empleo de las formas átonas de los pronombres personales es un hecho lingüístico que caracteriza al español frente a las demás lenguas románicas: ningún hablante de otro idioma vacila en el uso de los pronombres correspondientes. El leísmo, el laísmo y el loísmo son fenómenos típicos de la lengua española y producto, como es bien sabido, de la alteración del uso etimológico originario a causa de la confusión producida entre las formas de acusativo y las de dativo.

La repartición de tal uso está ligada a una variada distribución geográfica que sólo conocemos a grandes rasgos. Sabemos que, dentro de la Península, Andalucía es la región que se mantiene más cerca del uso latino, y, con ella, el sur de Extremadura y Canarias. Pero no quiere ello decir que -en tales zonas - sea exclusivo el uso etimológico, sino más bien predominante, ya que ha podido detectarse un cierto grado de leísmo en escritores andaluces ${ }^{1}$. Otro tanto sucede - como era de esperar- en Hispanoamérica, donde lo es la forma más extendida para la función de objeto directo masculino singular, si bien no la única, de modo que la alternancia entre lo y le corresponde - según parecea la lengua escrita y, ocasionalmente, al habla culta, sin que afecte al habla popular, que utiliza siempre $10^{2}$.

1 Cfr. Salvador Fernandez Ramfrez, Gramática española, Madrid, ed. Revista de Occidente, 1951, pág. 197.

2 La presencia de lésmo se da como indudable en Ecuador y Paraguay (cf. Charles KanY, Sintaxis Hispanoamericana, ed. Gredos, Madrid, 1969, págs. 133-135; 
Rufino José Cuervo señaló a Madrid y sus provincias circunvecinas como el centro del movimiento leísta ${ }^{3}$, desde donde fue irradiado el fenómeno a otras zonas, con mayor o menor intensidad, no bien determinada aún 4 . Este proceso de irradiación, comenzado desde antiguo, sigue actuando todavía hoy, hasta el punto de que áreas geográficas a las que el leísmo no afectó en épocas anteriores, se están viendo hoy invadidas por él ${ }^{5}$. De modo que es éste un fenómeno que tiene sus raíces en los orígenes de la lengua y que, aún hoy, no ha encontrado forma definitiva. El sistema latino se vio alterado en los primeros siglos del español y el reajuste a un nuevo sistema más estable (si no definitivo) no se ha producido por el momento. Otro tanto cabe señalar respecto al laísmo y loísmo, fenómenos encadenados al del leísmo, si bien de menor intensidad. Innecesario resulta caracterizar el laísmo como uso linguístico típicamente madrileño, no extendido - hoy por hoy- a zonas diferentes de las originarias. El loísmo, en cambio, parece revestir características socio-culturales más bien que geográficas.

Las causas que dieron lugar a la aparición del leísmo, laísmo y loísmo han sido objeto de diversos estudios. A Cuervo debemos el primer intento de esbozo histórico del problema ${ }^{\circ}$. Como complemento

Germán de Granda, «Origen y formación del leísmo en el español del Paraguay. Ensayo de un método», en El español de Paraguay. Temas, Problemas y Métodos, "Estudios Paraguayos», Asunción, 1979), a las que hay que añadir territorios leístas argentinos, cuando menos (cf. BerTa Elena Vidal de Batrini, «Zonas de leísmo en el espanol de la Argentinax, en Communications et Rapports du Premier Congrès International de Dialectologie Générale, II, Lovaina, 1964, págs. 160-163. Cf. también Juanita Carpora, *Lo and le in American Spanish», Hispania, 52(2), 1968, págs. 300302 y HaNs-Dibter PaUfler, "Quelques observations sur l'emploi des pronoms personells dans la variante cubaine de la langue espagnolex, en Actele celui de al XII-lea Congres International de Lingvistica si Filologie Romanica, II, Bucarest, 1971, págs. 1159-1164. Cf., también, Gustavo CantrRo Sandoval, «Casos de lefsmo en México», Anuario de Letras, XVII, 1979, págs. 305-308.

3 Cfr. Rufino José CulRvo, «Los casos enclíticos y proclíticos del pronombre de tercera persona en castellano», Romania, XXIV, 1895, págs. 95-113 y 219-263. (Citaré «Los casos»).

4 Salvador Fernandez Ramtrez, ha señalado en «Un proceso lingüistico en marcha», en Presente y Futuro de la Lengua Española, II, pág. 279, que «fuera de esas áreas más o menos homogéneas, poco sabemos hoy de la distribución geográfica de unas y otras formas. Ignoramos si existen límites claros, por ejemplo, entre un leísmo riguroso y un leísmo atenuado, dentro de la Península. Todo hace pensar que las diferencias entre las hablas individuales son en este punto innumerables y que más que de áreas y de dialectos cabe hablar aquí de idiolectos».

3 Cfr. Carmen Diaz CastaNón, «Algo sobre sintaxis del asturiano», REL, VI, 1976, págs. 363-367.

6 Cfr. Rufino José Cuervo, «Los casos», págs. 95-113 y 219-263. 
a su artículo están -sobre todo- los estudios de Salvador Fernández', de Rafael Lapesa ${ }^{8}$ y de Francisco Marcos 9.

$\mathrm{Si}$ atendemos al proceso histórico desde sus orígenes, observaremos que el punto de partida fue la confluencia en una misma forma lo de las latinas ILLUM e ILLUD, correspondientes, respectivamente, al acusativo masculino singular y al neutro, a causa de la evolución fonética. Con ello se borró la distinción genérica entre masculino y neutro. Junto a la forma sincrética lo, consecuencia de tal evolución fonética, el dativo le (forma tanto de femenino como de masculino) encerraba - ya desde el propio latín ILLI - un antiguo sincretismo al que vino a sumarse el anterior. Ello originó en la lengua la tendencia a diferenciar, por su parte, el género gramatical y, por otro lado, esta tendencia conllevaba la pérdida del sistema casual pronominal en las formas átonas de tercera persona. De modo que, en singular, la serie habría quedado constituida por una forma le (masculina), un femenino la y un neutro $l o$. Esta serie se habría visto favorecida, para su mantenimiento, por las de los demostrativos este / esta / esto, ese / esa / eso, aquel(le) / aquella / aquello y la serie personal tónica el(le) / ella / ello. Además, si atendemos a razones estructurales, observaremos que la extensión de le al acusativo encontraba su apoyo en las formas simétricas me y te, comunes ambas al dativo y al acusativo de singular de la primera y segunda personas. Consecuencia de ello fue que el leísmo cundiera más en singular que en plural, donde no cuenta -en romance- con una forma neutra y donde la oposición los / las guardaba perfecta correspondencia con la de ellos / ellas, estos / estas, esos / esas, aquellos / aquellas. Además, la forma los se veía reforzada, seguramente, por su semejanza con nos, vos y os. Este paradigma neológico tendía a eliminar la distinción casual, que no existe en los demás pronombres personales ni en los demostrativos, y a reforzar la distinción genérica, existente en todos ellos. Consecuencia de esta tendencia son: 1) la extensión del leísmo al acusativo de cosa, documentada desde muy pronto y con bastante intensidad (como veremos más adelante); 2) la extensión de la, las al dativo femenino, dando así origen al laísmo, fenómeno algo más tardío; 3) el ló́smo antietimológico en el plural, a costa del dativo masculino les, reforzado esto por el hecho de que no hay en plural formas

7 Cfr. Salvador Fernandez Ramtrez, Gramática española, Madrid, Revista de Occidente, 1951, págs. 182-212.

- Cfr. Rafael Lapesa, «Sobre los orígenes y evolución del leísmo, laísmo y loísmo», en Festschrift Walther von Wartburg, Tübingen, 1968.

- Cfr. Francisco Marcos MartN, Estudios sobre el pronombre, Madrid, Gredos, 1978. 
especiales para el dativo en los demostrativos y demás personales, así como tampoco en los afijos nos, os, y 4) el empleo de lo para el dativo neutro, fenómeno raro, pero existente ${ }^{10}$. El triunfo de esta tendencia habría dado lugar a un sistema coherente sin oposición de caso, que constaría de le, la, lo en singular (para masculino, femenino y neutro, respectivamente) y de los, las en plural (para masculino y femenino). Pero sucedió que el leísmo de cosa y el laísmo encontraron resistencia, e, incluso en zonas laístas, le y les no fueron nunca desbancados totalmente para la función de dativo femenino, al tiempo que le, para el dativo de cosa, no rebasaba las fronteras de Castilla y León. La intensidad del laísmo no alcanzó cotas tan altas como las del leísmo, y las del leísmo de cosa menos que las del leísmo de persona, y este último soportó todo el peso en el masculino. Además, el uso de los para el dativo masculino plural sufrió la competencia de la trasgresión contraria, esto es, la utilización de la forma les para el acusativo, arrastrada por el leísmo de singular, aunque en plural el leísmo fue menos intenso en todas las épocas. Por último, el empleo de lo para el dativo neutro ha sido siempre excepcional, añadiéndose a ello el hecho de haber surgido la forma to para el dativo masculino singular, forma contraria a la etimología y a la distinción genérica entre masculino y neutro.

Ahora bien, ha sido ya señalado que el leísmo primitivo nació como consecuencia de un hecho que se ha considerado peculiar de la forma linguiística interior del español, a saber, la tendencia a distinguir gramaticalmente las categorías de persona y de cosa ${ }^{\text {". }}$. Ligado a ello corre el fenómeno consistente en la propagación de $a$ ante objeto directo. El uso de $a$, en este caso, era el sustituto histórico del dativo latino, y tal propagación era especialmente notable, en su origen, ante el nombre o pronombre tónico representativos de persona individuada en función de objeto directo ${ }^{12}$. También el leísmo se concentra preferentemente en el área personal, como ha señalado Rafael Lapesa ${ }^{13}$. No hay que olvidar que, de acuerdo con los cómputos llevados a cabo por $\mathbf{H}$. Peine para el antiguo latín, el dativo se revela como un caso eminentemente personal ${ }^{14}$. La proporción latina, según la cual apenas poco más de la

10 Cfr. Rafael. Lapesa, ob. cit., pág. 548.

11 Cfr. Rafael LAPESA, «Evolución sintáctica y forma linguística interior en español», en Actas del XI Congreso Internacional de Lingüística y Filología Románica (Madrid, 1965), C. S. I. C., Madrid, 1968 y «Sobre los orígenes...», pág. 549.

12 Este es, justamente el punto de apoyo para la tesis de Harri Meier sobre la propagación de $a$ ante objeto directo. Cfr. HARRI MEIER, «Sobre as origens do acusativo preposicional nas línguas romanicas», en Ensaios de Filologia Romanica, Lisboa, Revista de Portugal, 1948, págs. 115-164.

13 Cfr. Rapabl Lapesa, «Sobre los orígenes», pág. 549.

14 Citado por Salvador Fernandez Ramfrez, Gramática, pág. 191. 
décima parte de los casos registrados dejan de ser personales, ha debido aumentar en español, ya sea por el desarrollo que en él han alcanzado estas clases de dativo personal que estamos viendo, ya sea por la desaparición de los dativos nominales, entre ellos el dativo final, que era exclusivamente de cosa ${ }^{15}$. De modo que la aplicación de un sintagma heredero del dativo al acusativo personal se sitúa en la misma línea que la confusión sufrida por las formas de dativo y acusativo en los pronombres átonos de tercera persona.

Hemos visto, hasta ahora, las tendencias - a veces contrarias- que han actuado y actúan en la dinámica interna de la lengua y que deciden el empleo de unas u otras formas de pronombres átonos de tercera persona. Nos falta por ver qué tendencias fueron preferidas en unas y otras épocas, y las causas primeras de su confusión. Ambas cuestiones han sido abordadas con detalle por Rafael Lapesa ${ }^{16}$ y por Francisco Marcos ${ }^{17}$. Gracias al trabajo de Rafael Lapesa sabemos que la perduración del dativo regido por un grupo considerable de verbos latinos, encuadrados todos ellos dentro del área personal, fue el punto de partida del leísmo; desde ahí se propagó a otros, llegando a invadir con fuerza dicha área personal ${ }^{18}$. Tales verbos eran intransitivos en latín (MINARE, menazar, amenazar; NOCERE, nozir; OBOEDIRE, obedecer; PARCERE, parcir; OBVIARE, uviar) o alternaban este régimen con el de transitivos con acusativo, ya como posibilidades indistintas, ya con alguna diferencia (ADJUTARE, ayudar; CURARE, curiar; SERVIRE, servir). Tales verbos, que en los textos antiguos rigen siempre $l e, 0$ alternan $l e$ y $l o$, pueden llevar -incluso hoy- la preposición $a$ ante el objeto de cosa, como corresponde a intransitivos, pero, al mismo tiempo, son susceptibles de ser puestos en pasiva. He aquí un segundo factor relacionado con nuestro asunto: el de la transitividad o intransitividad de los verbos espanoles.

Otra serie de factores contribuyeron, además, a la propagación del leísmo personal. Tales fueron las varias sustituciones de acusativos latinos por dativos en determinadas construcciones, a saber, el sujeto de infinitivo o de oración subordinada en función de objeto directo (que ya desde Tácito se encuentra con dativo, construido con JUBERE), las construcciones con verbos que en latín regían doble acusativo (en las

15 Cfr. Rufino José Cuervo, Diccionario de construcción y régimen de la lengua castellana, Bogotá, Instituto Caro y Cuervo, 1953, I, $9 \mathrm{~b}$.

16 En su citado artículo «Sobre los origenes».

17 En su citado libro Estudios sobre el pronombre, en el que se estudia con detalle todo lo referente al leísmo, laísmo y loismo, principalmente a partir del siglo Xv.

18 Cfr. Rafael Lapesa, «Sobre los orígenes*, págs. 527-535. 
que el primitivo acusativo de persona pasó a sentirse como objeto indirecto), las construcciones con objeto directo y complemento predicativo referente a él (en las que el acusativo pronominal latino se sustituye, desde muy pronto, por el dativo) y el dativo correspondiente al objeto de persona cuando hay un objeto directo de cosa, que mantiene la forma de dativo aún en los casos en que no hay objeto de cosa expreso ${ }^{19}$.

Esta continuidad del dativo latino regido por unos verbos y su propagación a otros, dentro del área personal, sirve de explicación a las vacilaciones que hoy se registran incluso en zonas que usan con preferencia $l o$ para objeto directo personal masculino ${ }^{20}$.

Ya hemos dicho antes que el resto de los fenómenos, esto es, el laísmo, el loísmo, el leísmo para persona o cosa femenina, el leísmo de cosa, el loísmo para dativo neutro, son fenómenos encadenados al del leísmo personal y menos intensos que él. Hasta ahora sabíamos que el laísmo es un fenómeno posterior al del leísmo y no teníamos ejemplos de él anteriores al siglo xIV, al menos ejemplos que ofrecieran cierta seguridad ${ }^{21}$, fenómeno cuyo uso progresará moderadamente hasta convertirse en predominante en autores como Calderón o Quevedo; la condena académica declarada en 1796 no ha conseguido desterrar tal uso del habla de Castilla y León, aunque sí ha puesto freno a su empleo literario. Sabíamos también que el loísmo antietimológico «aparece en plural antes y con más frecuencia que en singular 22 y su empleo en textos medievales había sido calificado de dialectal ${ }^{23}$. El loísmo para dativo neutro, así como el uso de le por lo neutro acusativo, se consideraba excepcional ${ }^{24}$ e incluso casi inexistente ${ }^{25}$. Asimismo, se había constatado que el lésmo era un fenómeno intenso en menor medida en plural que en singular ${ }^{2}$, mucho menos frecuente para la mención de cosas que para la designación de personas ${ }^{27}$ y menos frecuente, a su vez, para antecedente femenino que masculino 23 .

Aquí viene la justificación de nuestro trabajo. Porque, si bien es cierto que los estudios citados anteriormente son todos merecedores

19 Esto lo había señalado ya Rufino Josk CuERvo, en «Los casos», págs. 237-238.

20 Cfr. RApari. LAPBsa, ob. cit., págs. 537-538 y Franctsco MArcos MArTN, Estudios sobre el pronombre.

21 Cfr. RAFABI. LAPBSA, ob. cit., págs. 544545.

2 Ibidem, pág. 546.

23 Ibidem, pág. 547.

24 Ibidem, pág. 548.

25 Cfr. Rupino José Curarvo, aLos casos», pág. 113.

26 Cfr. Rafaza lapbsa, ob. cit., pág. 539.

27 Ibidem, pág. 542.

28 Ibidem, pág. 538. 
de los mayores elogios, también en ellos encontramos lamentos referidos a la escasez de datos para los primeros siglos de nuestra lengua. En efecto, se habian trazado, hasta ese momento, las directrices principales de los diferentes fenómenos, pero se desconocía la frecuencia de su aparición en los textos antiguos, el momento en que un determinado verbo había sustituido la forma lo del acusativo por la del dativo le (para la función de objeto directo), la vitalidad y extensión, en suma, de cada uno de los fenómenos en los orígenes y primeros siglos de nuestra lengua ${ }^{29}$. Nosotros hemos abordado esta tarea, conscientes de la importancia del estudio histórico en un tema como éste, en el que la inestabilidad y variedad en el uso de unas y otras formas es consecuencia de la lucha que la lengua tiene entablada consigo misma desde sus primeros tiempos. Para ello hemos seleccionado 35 textos antiguos que nos han proporcionado más de 40.000 ejemplos de pronombre átono de tercera persona ${ }^{30}$. La recogida de datos la hemos llevado a cabo manualmente. El material así recolectado ha sido cuidadosamente estudiado y clasificado de acuerdo con una serie de criterios que iremos viendo en las páginas siguientes.

De modo que este trabajo constituye una monografía sobre uno de los problemas que la sintaxis histórica de nuestra lengua tiene planteados. Sería nuestro deseo contribuir a un mejor conocimiento de la historia del español. Ofrecemos, pues, este estudio lingüístico sobre el leísmo, laísmo y loísmo en español antiguo, estudio que aporta un caudal de datos nuevo y que ha sido abordado con una metodología histórica.

\section{CUESTION METOdOLOGICA}

El correcto planteamiento metodológico es el primer punto que debe tenerse en cuenta al emprender un estudio linguístico enfocado históricamente. Ello no es tarea fácil. Un estudio de este tipo ha de estar basado, forzosamente, en textos escritos, de donde se deriva una doble dificultad de interpretación: por una parte, resulta obvio que tales textos no pueden tomarse como fiel reflejo de la lengua hablada, por lo que, a cada paso, se impone una cautelosa labor de detección de todos aquellos elementos infiltrados en el texto que, en alguna medida, ofrezcan garantías que nos permitan considerarlo reflejo de la realidad

29 En el libro de Francisco Marcos Marfin, se ofrece abundante material nuevo para los siglos Xvi en adelante.

30 Véase en páginas siguientes los criterios que hemos seguido tanto para la selección como para la interpretación de los textos. 
lingüística del momento. Cuando ello no sea posible, los datos obtenidos no podrán considerarse sino ligados a las peculiaridades del texto. Por otra parte, los manuscritos que poseemos no corresponden - las más de las veces- a las redacciones originales; decidir entonces qué parte se debe al autor y qué alteraciones (conscientes o inconscientes) ha introducido el copista respecto al original, es tarea difícil y no siempre posible. El siguiente párrafo de Menéndez Pidal resume muy bien esta dificultad: * La elaboración y la trasmisión de una obra literaria antes de la imprenta es cosa muy distinta de lo que fue después. La tipografía hizo que la publicación de un libro, hecha antes mediante muy escasas copias, lentas y muy distanciadas en el tiempo y en el lugar, se convirtiese en un acto momentáneo, único y superabundante en ejemplares. La publicación impresa señala la terminación de la obra por parte del autor; todo lo que éste trabajó en elaborarla queda anulado en el olvido, $y$ todo cuanto trabaje después en corregir y perfeccionar lo impreso es nulo, si no hace una segunda impresión. Por el contrario, en la lentísima publicación manuscrita cada ejemplar tiene su individualidad: el autor retiene, corrige y modifica su manuscrito original, y de él hace sacar copias discrepantes según los distintos tiempos en que se sacaron, conforme a la demanda de los amigos o del público; y aun en el caso en que la copia se saque de alguno de los manuscritos lanzados por el autor a la publicidad, tendrá discrepancias, porque el copista medieval solía arrogarse facultades de colaborador. Por esto, de un modo o de otro, cuando de una obra medieval se conservan diversos manuscritos, suelen éstos ser bastante diversos entre sím ${ }^{31}$. Nosotros ratificamos plenamente este hecho con lo que hemos podido observar en el Libro de Alexandre: según se trate de su copia en el manuscrito «O» (correspondiente a fines del siglo xIII o principios del xIV, y leonés) 0 en el manuscrito $\propto P \star$ (del siglo $\mathrm{xv}$, aragonés) el tratamiento de los pronombres átonos de tercera persona (le, la, lo y sus plurales) ofrece marcadas diferencias. Pero no quiere esto decir que haya que adoptar una actitud escéptica, sino, simplemente, que es necesario imponerse un rigor metodológico grande. Porque, volviendo al ejemplo que el Libro de Alexandre nos ofrece, si bien es cierto que -en lo divergentenunca sabremos lo que debe restituirse al original, contamos, en cambio, con un caudal de coincidencias que nos pondrán sobre la pista de lo que debió ser la lengua del autor. Además, en ocasiones, disponemos de ediciones críticas de los textos en las cuales, gracias a determinados factores, como puede ser la métrica, es posible recomponer el texto

31 Rumón Mandéndez Pidal, edición de la Primera Crónica General de España, Madrid, Gredos, 1955, pág. XXIX. 
primitivo. Así, por ejemplo, en la edición crítica del Libro de Apolonio, hecha por Manuel Alvar ${ }^{32}$, podemos determinar -atendiendo a las exigencias métricas- cuáles son las formas plenas lo o le que deben ser restituidas por la apocopada $l^{\prime}$. Claro, en los casos en que no deba restituirse la apócope, no sabremos si el original ofrecía lo o le. Por otra parte, este método no es aplicable a los textos escritos en prosa y así, por ejemplo, las reconstrucciones de formas apocopadas que Menéndez Pidal hizo en la Historia Troyana ${ }^{33}$ afectan solamente, como es obvio, a los fragmentos en verso $y$, en este caso, tales reconstrucciones nos resultan poco aprovechables, pues la mayor parte de casos de apócope que ofrecen interés para nosotros se encuentran, justamente, en los fragmentos en prosa. De manera que el camino hacia estudios de tipo histórico está lleno de dificultades, lo cual -insistimos una vez másno creemos que haya de ser entendido como negativa a investigar en esa dirección, sino como precaución suma en la interpretación de los datos.

Nosotros, por nuestra parte, hemos tenido en cuenta los siguientes factores a la hora de emprender nuestro estudio, así como a la de interpretar los resultados: 1) en ningún momento hemos dejado de considerar que trabajamos sobre datos proporcionados por la lengua escrita; 2) como base de nuestro estudio hemos seleccionado un núcleo de textos conservados en manuscritos originales, a saber, El Fuero de Valfermoso de las Monjas ${ }^{34}$, El Fuero de Madrid ${ }^{35}$, El Liber Regum ${ }^{36}$, La Fazienda de Ultramar ${ }^{37}$, Los Diez Mandamientos ${ }^{3}$, el manuscrito

32 Cfr. Manurl Alvar, edición del Libro de Apolonio, Madrid, Fundación Juan March y editorial Castalia, 1976.

33 Cfr. Ramón Meńndez Pidal, edición de Historia Troyana en prosa y verso, $R F E$, anejo XVIII, Madrid, 1934.

34 Fue otorgado este fuero en 1189 y conservamos el manuscrito original. Cfr. Ramón Mrnándrz Pidal, Crestomatía del español medieval, tomo I, Madrid, Gredos, 1971, 2.a edición.

35 La redacción de este texto se llevó a cabo en diversas etapas, a las que corresponden diferencias de lenguaje, comprendidas, probablemente, entre los años 1170-1202. Cfr. RAPABl LAPBSA, estudio lingüístico del Fuero de Madrid, Madrid, Ayuntamiento de Madrid, Archivo de Villa, 1962, pág. 152.

36 Es éste un texto compuesto entre 1194 y 1211 en navarro-aragonés. Cfr. Louis COOPER, El Liber Regum, estudio lingüístico, Zaragoza, Institución «Fernando el Católico», 1970, pág. 7.

37 Es el texto que nos plantea los primeros problemas. El editor, Mosin LazAr, pretendió que había sido redactado antes de 1153 (cfr. MosHó LAzAR, edición de La Fazienda de Ultramar, en «Acta Salmanticensia», Salamanca, 1965, págs. 10-13), pero tal intento ha sido rebatido contundentemente con posterioridad (cfr. FílIX LecoY, reseña a la edición de La Fazienda de Ultramar hecha por Moshis Lazar, Romania, XC, 1969, págs. 574-576, y Alberto VARVARo, reseña a la edición de la Fazienda de Ultramar hecha por Moshé LAzAR, Romance Philologie, 1969, págs. 239-244). Nosotros creemos que pertenece a la primera mitad del siglo xIII y tenderiamos a situarlo

LXI. -9 
I-I-6 de la Biblia Escurialense ${ }^{39}$, las obras alfonsíes El Libro conplido en los judizios de las estrellas ${ }^{10}$ y El Libro de açedrex ${ }^{41}$ y los Documentos Lingüísticos de España. Reino de Castilla ${ }^{42}$. Otros textos estudiados se conservan en manuscritos no muy distantes del original, como el Auto de los Reyes Magos ${ }^{43}$, la Razón de Amor ${ }^{4}$, Poridat de Poridades ${ }^{45}$, el manuscrito $₫ \mathrm{O}$ * del Libro de Alexandre ${ }^{46}$, el Fuero de Alba de Tormes ${ }^{47}$

más bien hacia bien entrada dicha primera mitad. La falta de un estudio lingüístico profundo de este texto nos impide hacer mayores precisiones.

38 Este breve texto, insertado, junto con otras dos obritas en castellano, en un manuscrito latino del sur de Francia, parece corresponder, atendiendo a su lengua, a la primera mitad del siglo xiII. Cfr. A. Morel Fatio, «Textes castillans inédits du XIIIe sièclex, Romania, 16, 1887, pág. 365.

39 Este texto es una traducción de la Vulgata y contiene toda la Biblia a partir de los Proverbios de Salomón. Nosotros hemos utilizado únicamente la parte correspondiente al Nuevo Testamento, pues el Antiguo Testamento, si bien se nos ha transmitido en un manuscrito idóneo para nuestro estudio en cuanto a su fiabilidad, apenas ofrece unos pocos ejemplos de pronombre átono de tercera persona (debido a la propia naturaleza del discurso). La datación de este texto ha sido objeto de diferentes opiniones; nosotros aceptamos la de Thomas MonTGomery, que lo sitúa en el siglo XIII, hacia su tercer cuarto, saunque no puede excluirse la posibilidad de que sea de fecha más antigua» (cfr. Thomas Montgomery, y SPURgeon W. BALWIN, edición de El Nuevo Testamento según el manuscrito escurialense I-I-6, anejo XXII del B. R. A. E., Madrid, 1970, pág. 5.

- Esta obra alfonsí, perteneciente a la primera etapa de actividad de las escuelas alfonsinas, se conserva escrita en su manuscrito original del siglo xilr. Hay pruebas concluyentes de que Yehudá b. Mošé empezó a traducirlo del árabe al castellano en el mes de marzo de 1254. Cfr. GrRold Hilty, edición de El Libro conplido en los judizios de las estrellas (traducción hecha en la corte de Alfonso el Sabio), Madrid, Real Academia Española, 1964, pág. LXV.

41 Pertenece esta obra a la segunda etapa de actividad de las escuelas alfonsinas, al igual que la anterior. Desconocemos la fecha en la que comenzó a redactarse, pero sabemos que el terminus ad quem de la obra corresponde al año 1283. Cfr. ARnald Striger, Libros de agedrex, dados e tablas, Romanica Helvetica, volumen 10, Ginebra-Zürich, 1941, pág. 15.

12 Constituyen la base más adecuada para un trabajo como el nuestro, ya que cada uno de ellos va acompañado de la fecha y lugar precisos de redacción.

43 Su fecha de composición debe situarse en la segunda mitad del siglo XII, pero el fragmento que de él conservamos corresponde a los primeros años del siglo xili. Cfr. Ramón Mrnéndez Pidal, edición del Auto de los Reyes Magos, Rabm, II, 1900, 3. época, pág. 453.

4 Compuesta hacia 1205, el manuscrito que ha llegado hasta nosotros (el más antiquo) es de la primera mitad del siglo xirr. Cfr. RAMón Meńandez Pidal, eSiesta de Abril (Razón de Amor con los Denuestos del Agua y el Vino)», Revue Hispanique, XIII, 1905, págs. 603 y sig.

is La obra parece compuesta a mediados del siglo XIII, tal vez a fines del reinado de Alfonso X. El manuscrito sobre el cual está hecha la edición que hemos utilizado (y que es el más antiguo de los que se conservan) es de fines del siglo XIII o principios del xIv. Cfr. LloYd A. KASTRN, edición de Poridat de las poridades, Madrid, 1957, pág. 10 y pág. 20.

* Es el más cercano al original de los manuscritos conservados. La opinión más común suele situar la composición del texto en la primera mitad (avanzada) 
y el Fuero de Teruel ${ }^{48}$, o se nos han transmitido en manuscritos de cuya fiabilidad existen garantías, tal como sucede con las obras de Berceo ${ }^{4}$. En algunos casos, como el Libro de Apolonio ${ }^{50}$ o la Vida de Santa

del siglo xIII. Este manuscrito $« O$, se considera perteneciente a finales del siglo xiII o bien entrado el siglo xiv y presenta rasgos leoneses. Cfr. Emilio Alarcos LLORACH, Investigaciones sobre el «Libro de Alexandre», C. S. I. C., Anejo XLV de la $R F E$, Madrid, 1948, págs. 15-16 y pág. 11.

47 Otorgado a finales del siglo XIII, el manuscrito que de él se conserva es, asimismo, de fines del siglo xili. Cfr. Américo Castro, y Federico de Onts, edición de los Fueros leoneses de Zamora, Salamanca, Ledesma y Alba de Tormes, Madrid, Centro de Estudios Históricos, 1916, pág. 290.

48 Otorgado hacia 1300, conservamos varios manuscritos, el más antiguo de los cuales es de principios del siglo xIv. Cfr. MAX Gorosch, edición de El Fuero de Teruel, en «Leges Hispanicae medii aevii», Estocolmo, 1950, pág. 11.

4 Sabido es que han existido tres manuscritos generales de sus obras: dos medievales y uno del siglo xvirr. Los medievales son los llamados $Q$ (manuscrito del siglo XIII, hoy perdido) y $F$ (manuscrito del siglo xIV, del que se conservan varios fragmentos). El tercero es $I$ (llamado ade Ibarreta»), copia del siglo XvIII y fuente principal de todo cuanto sabemos del manuscrito perdido $Q$. Los textos que nosotros hemos estudiado son los siguientes, que enumeramos por orden cronológico: la Vida de San Millán, escrita antes de 1230; la Vida de Santo Domingo, escrita hacia 1236; el Duelo de la Virgen; Himnos, los Loores de Nuestra Señora; Los signos del Juicio Final, entre 1236 y 1246, y los Milagros de Nuestra Señora, obra iniciada antes de 1246 . Se considera a $I$ como copia bastante esmerada de $Q$. Tal copia ha servido de base a la edición que BrIan Dutron ha hecho (y que nosotros hemos seguido) de la Vida de San Millán, Milagros de Nuestra Señora, el Duelo de la Virgen, Himnos, Los signos del Juicio Final y los Loores de Nuestra Señora (junto con el manuscrito $F$ ). De la Vida de Santo Domingo conocemos tres manuscritos: el llamado $S$ (copiado en el siglo xIII o XIv); $H$, que es una copia, a su vez, del anterior, hecha en el siglo xIv, y el manuscrito $E$ (de la Real Academia Española). Nosotros hemos tomado los datos a través de la edición que del manuscrito $S$ hizo Fray Alfonso Andrés. Cfr. BRIAN Dutron, ed.: La «Vida de San Millán de la Cogolla* de Gonzalo de Berceo. Estudio y edición crítica, Londres, Tamesis Books Ltd., 1967, pág. 65, «A Chronology of the Works of Gonzalo de Berceox, en Medieval Hispanic Studies presented to Rita Hamilton, Londres, 1975, págs. 67-76, edición de Gonzalo de Berceo. Obras Completas II. Los Milagros de Nuestra Señora, Londres, Tamesis Books Ltd., 1971, pág. 17, y tomos I y III; Carroll A. Marden, Cuatro Poemas de Berceo (Milagros de la Iglesia robada y de Teofilo, y Vidas de Santa Oria y de San Millán), Anejo IX de la RFE, Madrid, 1928, pág. 9; Fray Alponso Andrés, O. S. B., edición de Berceo. Vida de Santo Domingo de Silos. Edición critico-paleografica del Códice del siglo XIII, Madrid, Padres Benedictinos, 1958 y Claudio Garcta TURZA, «La tradición manuscrita de Berceo», Tesis doctoral presentada en la Universidad de Navarra, en el mes de abril de 1978.

50 Casi todos los autores coinciden en que el poema fue compuesto en el siglo xIII y, seguramente, hacia su mitad, tal como fue subrayado por Carroll Marden. Pero el manuscrito que nos ha llegado es el mismo que contiene la Vida de Santa María Egipciaca y el Libro de la Infancia y Muerte de Jesús (III-K-4 de la Biblioteca escurialense) que debió ser copiado a finales del siglo xrv por un escriba aragonés. Cfr. Charlas Carroll marden, El alibro de Apolonio». An old spanish poem, Baltimore, 1917 (utilizamos la reimpresión de Nueva York, Klaus Reprint Corporation, 1965, tomo I, págs. XIX-XXII y XXI-XXII; ManuRL Alvar, Vida de Santa María Egipciaca, C. S. I. C., «Clásicos Hispánicos», I, Madrid, 1970, págs. 6-7. 
Maria Egipciaca ${ }^{51}$, contamos con ediciones críticas que nos permiten conocer, mediante reconstrucciones métricas, las formas pertenecientes al manuscrito original, siquiera sea parcialmente. Por último, y pese a las dificultades de interpretación que sus datos puedan entrañar, hemos elegido algunos textos que consideramos de gran importancia, tales como Elena y Maria ${ }^{52}$, la Historia Troyana ${ }^{53}$, Roncesvalles ${ }^{54}$, el Libro de la Infancia y Muerte de Jesús 55 y el manuscrito «P» del Libro de Alexandre 56; 3) hemos tomado como punto de referencia la fecha de copia del manuscrito, y no la de su composición, en aquellos casos en los que no contamos con el manuscrito original. Nos ha decidido a ello el hecho, ya apuntado más arriba, de que un texto como el Libro de Alexandre ofrece divergencias según se trate de su copia en el manus-

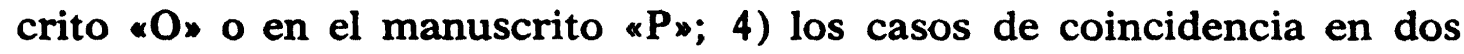
manuscritos diferentes de un mismo original, los hemos considerado pertenecientes al texto primitivo; 5) ya hemos indicado que la edición crítica del Libro de Apolonio nos ha permitido restituir el porcentaje correcto de apócope que el manuscrito original debía ofrecer, lo que ha hecho posible su comparación con los datos del manuscrito en el que se nos ha transmitido el texto; 6) asimismo, ha sido provechoso el resultado que la comparación entre los manuscritos «O $\mathrm{O}$ y «P» del Libro de Alexandre nos ha proporcionado, pues, si bien no nos es conocido el manuscrito original, las diferencias entre uno y otro (y no sólo las

51 Parece que su composición puede considerarse procedente de alguno de los cenobios riojanos que fueron célebres en los albores del siglo xIII, pero el manuscrito que poseemos debió ser copiado a finales del siglo XIV por un escriba aragonés. Cfr. nota anterior.

52 La fecha de composición debemos situarla hacia 1280, pero el manuscrito que conservamos corresponde a principios del siglo Xiv. Cfr. RAMón MEnéndez Pidal, edición de «Elena y Maria», RFE, I, 1914, pág. 53.

53 En opinión de MENŔNDzz PIDAL, la obra fue escrita hacia 1270; el manuscrito conservado presenta letra de mediados del siglo xiv. Cfr. Ramón Meñ́ndez Pidal, edición de la Historia Troyana en prosa y verso, Anejo XVIII de la RFE, Madrid, 1934, págs. IX-XX.

54 Texto compuesto, en opinión de Menéndez Pidal, a principios del siglo xIII; se conserva un fragmento de principios del XIV, navarro-aragonés. Cfr. RAMON MENéNDRz PIDAl, «Roncesvalles», un nuevo cantar de gesta español del siglo XIII», RFE, abril-junio, 1917, pág. 107 y pág. 198.

55 Se conserva en el mismo manuscrito que la Vida de Santa Maria Egipciaca y el Libro de Apolonio (cfr. la nota 50), pero su redacción hay que situarla en la primera mitad del siglo xIII. Cfr. MANURL Alvar, Libro de la Infancia y Muerte de Jesús (Libre dels tres Reys d'Orient), C. S. I. C., «Clásicos Hispánicos», Madrid, 1965, pág. 39.

56 Dista este manuscrito del original al menos siglo y medio, ya que pertenece al siglo xv. Cfr. Emilo Alarcos llorach, ob. cit., pág. 11. Pese a ello, nos ha resultado de gran utilidad, pues permite la comparación con el manuscrito «O». 
semejanzas, como hemos apuntado más arriba) han sido útiles, como veremos en su momento.

De manera que los datos proporcionados por cada uno de los textos requiere una cuidadosa labor de interpretación, tal como se desprende de todo lo dicho anteriormente. No olvidemos, además, que trabajamos sobre textos escritos y que éstos, por lo común, se atienen a convenciones de carácter generalmente conservador, y unos más que otros. Nuestra tarea será, pues, adivinar el correcto sentido de su desviación. Recordemos un párrafo de Luis Michelena que resume muy bien el sentido de nuestro quehacer: «el andamiaje más o menos estable de hipótesis sobre lo no directamente conocido, sólo puede sostenerse sobre el fundamento de la historia, de los estados documentados de lengua, y no existe más que en función de ella, puesto que su valor suele ser en la práctica equivalente a su capacidad de iluminar estos estados» ${ }^{57}$.

\section{ANALISIS DE DATOS}

\subsection{PRONOMBRE APOCOPADO "L'» EN FUNCIÓN DE OBJETO DIRECTO.}

La naturaleza de la vocal perdida en el pronombre apocopado - $l$ ' ha sido objeto de diferentes interpretaciones. Para Gessner, - $l$ ' era la forma resultante tanto de la apócope de lo como de $l e^{58}$. Cuervo, sin embargo, pensó que - $l$ ' no podía ser producto de la apócope de $l 0^{59}$ y esta misma imposibilidad fue defendida por Staaff ${ }^{60}$ y Menéndez Pidal ${ }^{61}$. Para nos-

5 Cfr. Luis Michelexa, Lenguas y protolenguas, en aActa Salmanticensia», Salamanca, 1963, pág. 15.

58 Cfr. GessNer, ZRPh, XVII, pág. 9.

59 Cfr. Rupino José Cuervo, «Los casos», págs. 234-235. Su argumentación está basada en el hecho de que, en el escrutinio que llevó a cabo en los textos por él estudiados, no encontró ejemplo alguno en el que $-l$ ' estuviese por lo neutro, asi como, por otra parte, observó que los textos en los que le nunca (o raramente) hace oficio de objeto directo, tampoco $-l$ ' desempeña tal función. Respecto a la primera cuestión cabe argumentar, tal como ha hecho RAFAEL LAPESA (véase la nota 62) que ciertos fenómenos fonéticos van ligados a categorias gramaticales concretas. Aparte de que sí hay algún ejemplo en el que se ha apocopado el lo neutro; asi, en el Libro de Alexandre hemos encontrado este caso en el manuscrito "Ox, que resulta más claro si lo comparamos con el manuscrito «P»: «Descubriose el boço quando ouo de fablar / cato contra Paris començo de çeñar / dixo sy quieres Paris el derecho judgar / ya lo puedes ver quj la deue leuar [la manzana]» (379, pág. 72, ms. «P»); «Descobrio ela faz ouo de fablar / cataua contra Paris compeçol daçennar / dixo se quisieres Paris el derecho iudgar / yal uees por loio qui la deue leuar» (Ibid., ms. «O»). Respecto a la segunda cuestión, veremos en las páginas siguientes que no se cumple en nuestros textos.

60 Cfr. StaApr, Etude sur les pronoms abregés en ancien espagnol, Upsala, 1906, págs. 1-11.

61 Cfr. Ramón Menéndez Pidal, Manual de Gramática Histórica, Madrid, Espasa 
otros, el problema ha quedado zanjado con las puntualizaciones que Lapesa ha hecho sobre la cuestión ${ }^{62}$. Por lo tanto, en nuestro trabajo hemos separado, dentro de los casos de apócope, los que cumplen función de objeto directo, por una parte, y los que desempeñan función de objeto indirecto, por otra.

El interés que ofrecen para nosotros las formas apocopadas reside en la relación que tienen con el leísmo personal. Se ha pensado que «la homomorfia producida por la apócope contribuyó a que se confundieran las categorías de dativo y acusativo, y que, al restablecerse las formas plenas, la apocopada fue sustituida por le no sólo en el dativo, sino también - muchas veces- en el acusativo, por influjo de lo que ocurría con $m^{\prime}, t^{\prime}, s^{\prime}$, reemplazados por $m e, t e$, se sin distinción casual» ${ }^{63}$. Sin embargo, pareja a esta suposición surgía la sospecha de que la distinción entre dativo y acusativo subsistiera mentalmente bajo la forma común apocopada ${ }^{64}$. En las páginas que siguen estudiaremos estas consideraciones a la luz de los datos obtenidos por nosotros. Ofreceremos, por una parte, los porcentajes de $-l^{\prime}$ en función de objeto directo $y$, por otra, su comportamiento en relación con los porcentajes de lo y de le para la misma función.

Si examinamos los casos de apócope de objeto directo masculino personal, siguiendo un orden cronológico y tomando como punto de referencia para tal cronología la fecha de copia de los diferentes manuscritos, en los casos en los que no disponemos del manuscrito original, obtenemos la siguiente distribución de porcentajes:

\begin{tabular}{|c|c|c|c|}
\hline Fuero de Valfermoso de las Monjas & \multicolumn{2}{|c|}{0 casos } & $0 \%$ \\
\hline Fuero de Madrid & $\mathbf{0}$ & 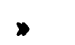 & $0 \%$ \\
\hline Los Diez Mandamientos & $\mathbf{0}$ & • & $0 \%$ \\
\hline Razón de Amor & $\mathbf{0}$ & • & $0 \%$ \\
\hline Liber Regum & $\mathbf{0}$ & 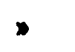 & $0 \%$ \\
\hline Auto de los Reyes Magos & 2 & • & $20 \%$ \\
\hline La Fazienda de Ultramar & 103 & & $29,2 \%$ \\
\hline La Vida de San Millán & 5 & » & $8,92 \%$ \\
\hline La Vida de Santo Domingo & 8 & » & $8,8 \%$ \\
\hline
\end{tabular}

Calpe, 1968, 13.* edición, párrafo 944, y Cantar de Mio Cid. Texto. Gramática y vocabulario, Madrid, Espasa Calpe, 1964, 4.* edición, págs. 251, 321 y 322.

62 Cfr. Rapaer. Lapresa, «Sobre los origenes», págs. 524 y 525 . Ha defendido la posibilidad de que, en función de acusativo, $-l$ ' pueda proceder de $l o$, basándose en el hecho de que, por fonética sintáctica, la -o final puede desaparecer, al igual que desaparecía en los nombres propios ante patronímicos en castellano medieval, y argumentando que, el hecho de que el lo neutro no se apocope, no es obstáculo para suponer que sí pueda hacerlo el lo masculino, pues no es desconocido que fenómenos fonéticos vayan ligados a categorías gramaticales determinadas.

63 Ibidem, pág. 525.

4 Ibidem, pág. 526. 


\begin{tabular}{|c|c|c|}
\hline El Duelo de la Virgen & 0 & $0 \%$ \\
\hline Loores de Nuestra Señora & 15 & $51,72 \%$ \\
\hline Los Signos & 0 & $0 \%$ \\
\hline Milagros de Nuestra Señora & 11 & $10,1 \%$ \\
\hline Libro de Apolonio (original) 65 & 28 & $28,57 \%$ \\
\hline Evangelio de San Mateo & 76 & $55,47 \%$ \\
\hline Evangelio de San Marcos & 72 & $48,64 \%$ \\
\hline Evangelio de San Lucas & 121 & $68,36 \%$ \\
\hline Evangelio de San Juan & 80 & $66,66 \%$ \\
\hline Hechos de los Apóstoles & 86 & $58,1 \%$ \\
\hline Epistolas & 70 & $66,03 \%$ \\
\hline Apocalipsis & 5 & $71,42 \%$ \\
\hline Libro conplido & 33 & $77,63 \%$ \\
\hline Libro de açedrex & 135 & $50,56 \%$ \\
\hline Poridat de Poridades & 25 & $45,6 \%$ \\
\hline Fuero de Alba de Tormes & 13 & $9,77 \%$ \\
\hline Libro de Alexandre (manuscrito «O») & 118 & $29,28 \%$ \\
\hline Elena y María & 0 & $0 \%$ \\
\hline Roncesvalles & 0 & $0 \%$ \\
\hline Historia Troyana & 15 & $4,1 \%$ \\
\hline Fuero de Teruel & 0 & $0 \%$ \\
\hline Libro de Apolonio & 19 & $19,9 \%$ \\
\hline Vida de Santa Maria Egipciaca & 6 & $40 \%$ \\
\hline Libro de la Infancia y Muerte & 5 & $29,4 \%$ \\
\hline Libro de Alexandre (manuscrito $\propto \mathbf{P}_{\Downarrow}$ ) & 61 & $15,97 \%$ \\
\hline
\end{tabular}

Podemos apreciar que los textos castellanos tempranos no ofrecen casos de apócope para esta función, así como tampoco el Liber Regum. Es éste un hecho curioso, pues tales textos corresponden a una época de gran auge de la apócope en otros casos ${ }^{6}$. Sí la ofrece el Auto de los Reyes Magos, también la Fazienda y las obras de Berceo. El manuscrito I-I-6 de la Biblia aumenta el porcentaje considerablemente. Debemos señalar aquí que puede haber cierta relación con el hecho de que la obra de Berceo que mayor porcentaje de apócope ofrece es Loores, obra en la que se ha señalado probable influencia del manuscrito escurialense I-I-6, dada la coetaneidad de este manuscrito con algunas obras de Berceo ${ }^{67}$. La elevación en el porcentaje afecta, de una manera

65 Gracias a la edición critica del Libro de Apolonio hecha por Manurl Alvar, hemos podido obtener los porcentajes correspondientes a la obra original. Compárese con el porcentaje que arroja el manuscrito en el que se ha copiado el texto (página siguiente).

66 Cfr. Rafael Lapesa, «La apócope de la vocal en castellano antiguo. Intento de explicación históricax, en Estudios dedicados a Menéndez Pidal, C. S. I. C., II, Madrid, 1951, pág. 208.

67 Así lo ha sugerido Brian DutTon, en edición de Gonzalo de Berceo. Obras Completas, III, Londres, Tamesis Books Ltd., 1975, pág. 4. 
muy marcada, al Libro conplido, que ofrece la cifra más elevada. Es éste un fenómeno que no nos sorprende, ya que tal obra corresponde a una época en la que aún no se ha producido, por parte de Alfonso $\mathbf{X}$, la conocida reacción en contra del uso de la apócope ${ }^{68}$. En cambio, deberíamos esperar que esta reacción se reflejase en El Libro de açedrex, obra terminada en 1283, y esto no sucede, ya que el porcentaje desciende bastante respecto al Libro conplido, pero sigue siendo semejante al ofrecido por el manuscrito I-I-6 de la Biblia. Sin embargo, el hecho sí está reflejado, de alguna manera, en el texto. Veámoslo: en dicho texto, el verbo poner ofrece 107 casos de apócope y 46 casos de lo. Pues bien, los ejemplos de apócope llegan hasta la 262 (que corresponden al final de la jugada 94) y, a partir de ahí, no hay ningún caso más de apócope; y, de los 46 casos de 20,10 aparecen antes de la página 262 y los 36 restantes se encuentran a partir de la página 263. Se puede apreciar, pues, claramente, que ha habido un cambio brusco en el empleo del pronombre átono apocopado: su uso se rechaza a partir de determinado momento, o, por lo menos, se evita. La tentación de pensar que este momento corresponde al de la decisión del monarca de no utilizar formas apocopadas es bastante grande, sobre todo si tenemos en cuenta que no nos es conocida la fecha en la que comenzó a escribirse el Libro de açedrex y que este dato podría resultar útil para fechar una parte del texto. Y no sólo podemos observar esta preferencia con el verbo poner; el hecho es claro en todos los casos de apócope, pues, de los 136 ejemplos que registra el texto, sólo 2 sobrepasan la página 263.

Si seguimos analizando el resto de los porcentajes, observaremos que el Poridat de Poridades presenta uno similar al ofrecido por la Biblia. La coetaneidad de estos textos parece no ofrecer dudas, pues no sólo se asemejan en el uso del pronombre apocopado -l', sino también en el de las formas le, lo y sus plurales, como veremos más adelante.

El Fuero de Alba de Tormes muestra una disminución clara en el porcentaje de apócope; no olvidemos que nos estamos situando ya a fines del siglo XIII. El porcentaje sigue siendo bajo en la Historia Troyana y nulo en Elena y María, Roncesvalles y Fuero de Teruel. Podemos pensar que la Historia Troyana es un reflejo de la reacción castellana contra el empleo de la apócope ${ }^{\oplus}$, o bien puede explicarse el bajo porcentaje de la misma por la tardía fecha de copia del texto.

- Tal reacción parece corresponder a la fecha de 1276, como expone RafapI LAPBsA, en «La apócope», pág. 219.

- Esta idea ha sido apuntada por Manuzl Alvar, en su edición del Libro de Apolonio, I, pág. 78. 
Pero nos quedan aún algunos textos por analizar, que ofrecen ciertos problemas. Por una parte, el porcentaje correspondiente a la obra original del Libro de Apolonio (28,57\%) está acorde con el que ofrece la Fazienda de Ultramar, sin llegar a los arrojados por los diferentes fragmentos de la Biblia, texto que debe ser posterior al Libro de Apolonio. En la copia que conservamos de él, perteneciente a fines del siglo XIv, el porcentaje ha disminuido $(19,9 \%)$ aun a costa de violar la métrica del poema ${ }^{70}$; vemos, pues, que existe la tendencia a rebajar el porcentaje de apócope, pero no a eliminarlo totalmente, lo que indica que el copista respeta el original en un cierto grado, aunque no totalmente. Si el amanuense que copió, a fines del siglo xIv, el Libro de Apolonio, se hubiese dejado llevar de sus propias preferencias en el uso de formas apocopadas y formas plenas, seguramente el porcentaje de apócope habría sido nulo.

Lo mismo sucede con el Libro de Alexandre: su copia en el manuscrito $\propto 0$ », hecha a fines del siglo xIII o principios del XIV, nos muestra un porcentaje de formas apocopadas $(23,45 \%)$ superior al que arroja la copia «P» $(15,97 \%)$, correspondiente a principios del siglo xv. Con el paso del tiempo, se advierte la tendencia a disminuir los casos de apócope. No sabemos cuál era el porcentaje que habría arrojado el texto original, pero podemos sospechar que fue algo mayor del que ofrece el manuscrito «O». Concordaría, en ese caso, con el ofrecido por el texto original del Libro de Apolonio, hecho éste totalmente lógico, si atendemos a la fecha de composición de ambos textos.

Estas dos obras nos dan ocasión para conjeturar acerca de uno de los hechos que apuntábamos al principio: la restitución de las formas plenas, una vez pasado el auge de la apócope, ¿se hizo a base de le, tanto para la función de objeto directo como para la de objeto indirecto? No parece. Por una parte, el $9 \%$ de disminución que el Libro de Apolonio ofrece en la copia de fines del siglo xIV respecto del texto original, se ha repartido casi equitativamente entre los porcentajes de le y los de lo:

\begin{tabular}{|c|c|c|c|}
\hline & Apócope & lo & le \\
\hline $\begin{array}{l}\text { Libro de Apolonio } \\
\text { (texto original) }\end{array}$ & $28,57 \%$ & $59,18 \%$ & $12,24 \%$ \\
\hline $\begin{array}{l}\text { Libro de Apolonio } \\
\text { (copia del siglo xIV) }\end{array}$ & $19,9 \%$ & $64,64 \%$ & $16,16 \%$ \\
\hline
\end{tabular}

70 Como pone de manifiesto Mavurl Alvar, ob. cit., págs. 77 y sig. 
A su vez, la disminución que registra la copia en el manuscrito «P* el Libro de Alexandre respecto a su copia en el manuscrito «O», a saber, un $13 \%$, se ha repartido con el $8 \%$ para lo y el $5 \%$ para $l e$ :

\begin{tabular}{|c|c|c|c|}
\hline & Apócope & 10 & le \\
\hline $\begin{array}{l}\text { Libro de Alexandre } \\
\text { (manuscrito } \mathrm{O} \text { " }\end{array}$ & $29,28 \%$ & $66,24 \%$ & $4,46 \%$ \\
\hline $\begin{array}{l}\text { Libro de Alexandre } \\
\text { (manuscrito } \ltimes \mathrm{P} \text { ) }\end{array}$ & $15,97 \%$ & $74,87 \%$ & $9,65 \%$ \\
\hline
\end{tabular}

En apoyo de que la restitución de formas apocopadas no se hizo a base de $l e$, tanto para la función de objeto directo como para la de indirecto, vendría el hecho, señalado ya por Rafael Lapesa ${ }^{71}$, de que dicha restitución se hizo en Andalucía (donde la apócope tuvo su propia vitalidad) distinguiendo perfectamente $l e$ dativo y $l o$ acusativo.

Por su parte, un texto como la Historia Troyana, que corresponde, tal como acabamos de ver, a un momento decadente de la apócope, ofrece un porcentaje muy elevado de $l o$, en tanto que el de le sigue siendo bajo.

El hecho de que Lapesa señalara que el crecimiento del porcentaje de apócope, en algunos pasajes de la Primera Crónica General de España, se hubiera hecho principalmente a costa de $l o$, mientras que los porcentajes arrojados por los diferentes códices del Libro de Buen Amor reflejaran un descenso de apócope beneficioso tanto para lo como para $l e^{72}$, se explica porque tales fragmentos de la Primera Crónica General corresponden a un momento de especial auge del leísmo personal ${ }^{73}$, momento que no es ya al que pertenecen los de copia del Libro de Buen Amor, así como tampoco el de copia del Libro de Apolonio, del Libro de Alexandre (especialmente el manuscrito $\propto \mathrm{P}_{\star}$ ), o la Historia Troyana.

Por último, los porcentajes de formas apocopadas que ofrecen la Vida de Santa María Egipciaca y el Libro de la Infancia y Muerte de Jesús, textos que se nos han transmitido en el mismo manuscrito que el Libro de Apolonio, parece que pueden interpretarse como correspon-

71 Cfr. Rafael Lapesa, «Sobre los origenes», págs. 526 y 527.

7 Cfr. Ibidem, págs. 525 y 526.

73 Un estudio exhaustivo del uso de los pronombres átonos de tercera persona en la Primera Crónica General, así como de los problemas cronolónicos que plantea, puede verse en nuestra tesis doctoral sobre «Leísmo, laísmo y loísmo en español antiguo», lefda en octubre de 1977 en la Universidad Complutense de Madrid, págs. 173 y sig., y en nuestro artículo aApócope y leísmo en la Primera Crónica General. Notas para una cronologla», Studi Ispanici, Pisa, 1979, págs. 1-16. 
dientes a los textos originales, pero con una cierta disminución en las cifras respecto a ellos, tal como sucedía en el Libro de Apolonio. Vemos que, suponiendo una disminución semejante a la sufrida por el Libro de Apolonio, el Libro de la Infancia y Muerte de Jesús arrojaría porcentajes semejantes a los de la Fazienda de Ultramar y Libro de Apolonio, textos cercanos a él por el momento de composición. En cambio, las cifras suben mucho para el porcentaje de apócope en la Vida de Santa María Egipciaca, lo que, en principio, desnivelaría bastante la supuesta homogeneidad que hemos defendido entre los textos, pero téngase en cuenta que la Vida de Santa María Egipciaca, por el mismo asunto de que trata, es un texto que no reparte los casos de objeto directo masculino personal de forma regular, pues la mayoría de los casos van referidos a antecedente femenino, lo que hace de él un texto irregular en este sentido.

\subsection{LEISMO PERSONAL REFERIDO A ANTECEDENTE MASCULINO.}

El comportamiento de los pronombres átonos de tercera persona $l e, l a$, lo y sus plurales respectivos ofrece marcadas diferencias de acuerdo con la naturaleza del antecedente al cual van referidos. En el empleo de las formas plenas para objeto directo, la frecuencia de leísmo varía notablemente según el antecedente esté referido a persona masculina o femenina, singular o plural. De modo que, en nuestro análisis, separaremos cuidadosamente estos factores y trataremos de estudiar las tendencias de la lengua en unos y otros casos.

Para el estudio del leísmo personal referido a antecedente masculino, hemos observado y analizado los porcentajes que los diferentes textos arrojan en el empleo de las formas de singular le y lo, por una parte, y los correspondientes a las formas plurales los y les, por otra. Comenzaremos ofreciendo los porcentajes de le y $l o$ en función de objeto directo en los diversos textos. Téngase en cuenta que tales porcentajes no han sido elaborados solamente a base de las distintas frecuencias de $l o$ y $l e$ en cada texto, sino que se hallan relacionados con la frecuencia correspondiente a los casos de apócope para tal función, de manera que el $100 \%$ de los casos se obtendrá sumando los porcentajes de apócope más los de lo y le, en cada texto. Seguirán a continuación los porcentajes de plural. El $100 \%$ de los casos se obtendrá, aquí, sumando los casos de los y les, ya que la apócope, como es obvio, no existe en plural. 
2.2.1. Análisis de porcentajes de formas plenas de objeto directo masculino singular:

\begin{tabular}{|c|c|c|c|c|c|c|}
\hline \multirow{4}{*}{$\begin{array}{l}\text { Fuero de Valfermoso de las Monjas } \\
\text { Fuero de Madrid } \\
\text { Los Diez Mandamientos }\end{array}$} & \multicolumn{3}{|c|}{ LO } & \multicolumn{3}{|c|}{$L E$} \\
\hline & & asos & $(100 \%)$ & & casos & $(0 \%)$ \\
\hline & 31 & $\rtimes$ & $(100 \%)$ & $\mathbf{0}$ & $\star$ & $(0 \%)$ \\
\hline & 3 & » & $(100 \%)$ & $\mathbf{0}$ & » & $(0 \%)$ \\
\hline Razón de Amor & 1 & * & $(100 \%)$ & $\mathbf{0}$ & $\star$ & $(0 \%)$ \\
\hline Liber Regum & 74 & 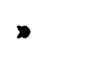 & $(98,6 \%)$ & 1 & 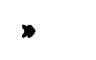 & $(1,3 \%)$ \\
\hline Auto de los Reyes Magos & 8 & * & $(80 \%)$ & 0 & • & $(0 \%)$ \\
\hline La Fazienda de Ultramar & 168 & $\star$ & $(47,59 \%)$ & 82 & • & $(23,25 \%)$ \\
\hline La Vida de San Millán & 45 & $\star$ & $(80,35 \%)$ & 6 & 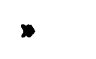 & $(10,73 \%)$ \\
\hline La Vida de Santo Domingo & 71 & $\bowtie$ & $(78,8 \%)$ & 11 & 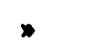 & $(12,2 \%)$ \\
\hline El Duelo de la Virgen & 31 & » & $(96,8 \%)$ & 1 & $\bullet$ & $(3,16 \%)$ \\
\hline Loores de Nuestra Señora & 13 & 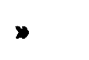 & $(45,2 \%)$ & 1 & 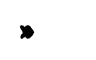 & $(2,9 \%)$ \\
\hline Los Signos & 1 & » & $(100 \%)$ & $\mathbf{0}$ & $\rtimes$ & $(0 \%)$ \\
\hline Milagros de Nuestra Señora & 88 & » & $(81,4 \%)$ & 9 & 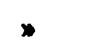 & $(8,3 \%)$ \\
\hline Libro de Apolonio (original) & 58 & 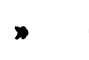 & $(59,18 \%)$ & 12 & • & $(12,24 \%)$ \\
\hline Evangelio de San Mateo & 14 & * & $(10,21 \%)$ & 47 & » & $(34,3 \%)$ \\
\hline Evangelio de San Marcos & 5 & » & $(3,38 \%)$ & 71 & 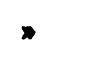 & $(47,9 \%)$ \\
\hline Evangelio de San Lucas & 7 & $\star$ & $(3,95 \%)$ & 49 & $\star$ & $(27,68 \%)$ \\
\hline Evangelio de San Juan & 6 & » & $(5 \%)$ & 34 & & $(28,33 \%)$ \\
\hline Hechos de los Apóstoles & 9 & » & $(6,08 \%)$ & 53 & » & $(35,8 \%)$ \\
\hline Epistolas & 4 & » & $(3,77 \%)$ & 32 & 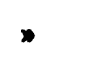 & $(30,18 \%)$ \\
\hline Apocalipsis & $\mathbf{0}$ & » & $(09$ & 2 & » & $(28,57 \%)$ \\
\hline Libro conplido & 74 & » & $(17,35 \%)$ & 21 & • & $(4,85 \%)$ \\
\hline Libro de açedrex & 126 & » & $(47,19 \%)$ & 6 & » & $(2,24 \%)$ \\
\hline Poridat de Poridades & 10 & » & $(17,72 \%)$ & 22 & $\star$ & $(38,59 \%)$ \\
\hline Fuero de Alba de Tormes & 106 & » & $(79,69 \%)$ & 14 & » & $(10,5 \%)$ \\
\hline Libro de Alexandre (ms. $\left.{ } \mathrm{O}_{\star}\right)$ & 267 & 》 & $(66,24 \%)$ & 18 & » & $(4,46 \%)$ \\
\hline Elena y Maria & 10 & » & $(90,9 \%)$ & 1 & » & $(9,9 \%)$ \\
\hline Roncesvalles & 4 & 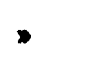 & $(80 \%)$ & 1 & $\star$ & $(20 \%)$ \\
\hline Historia Troyana & 301 & * & $(88,26 \%)$ & 25 & » & $(7,33 \%)$ \\
\hline Fuero de Teruel & 136 & & $(85,53 \%)$ & 23 & » & $(14,46 \%)$ \\
\hline Libro de Apolonio & 64 & » & $(64,64 \%)$ & 16 & • & $(16,16 \%)$ \\
\hline Vida de Santa María Egipciaca & 7 & » & $(46,6 \%)$ & 2 & $\bullet$ & $(13,3 \%)$ \\
\hline Libro de la Infancia y Muerte & 11 & & $(64,7 \%)$ & 1 & 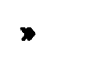 & $(5,896)$ \\
\hline Libro de Alexandre (ms. «P») & 286 & • & $(74,87 \%)$ & 35 & . & $(9,65 \%)$ \\
\hline
\end{tabular}

Como primer punto, tenemos que advertir un hecho que conlleva cierta desventaja respecto a los casos de apócope a la hora de interpretar los datos, y es que las ediciones críticas que se han hecho o pueden hacerse de textos como el Libro de Apolonio u otros, resultan de valiosísimo interés para estudiar la apócope, ya que la métrica es un factor que permite reconstruir las formas apocopadas originales, al mismo tiempo que hace posible la comparación de la obra original con 
el manuscrito o manuscrito correspondientes. No sucede lo mismo con los casos de le y lo. Evidentemente, la métrica no facilita, en este caso, la reconstrucción de las formas originales. No contamos, pues, con la posibilidad de comparar un texto original con un manuscrito posterior. Pero sí es posible determinar, en alguna medida, la variación de unas y otras formas, pues, como ya hemos advertido, los porcentajes de le y lo están elaborados con referencia a un tercer factor: la apócope. Dado que podemos restituir el porcentaje exacto de esta última en el texto original, podremos observar, al mismo tiempo, cómo se ha repartido entre le y lo la cantidad de porcentaje que ha variado. Algo de esto hemos hecho ya anteriormente al tratar de la apócope.

Del examen de los diferentes porcentajes de lo y $l e$, para la función de objeto directo masculino singular de persona, podemos determinar varios hechos. Por una parte, advertimos que textos tempranos, tales como el Fuero de Valfermoso de las Monjas, Los Diez Mandamientos, la Razón de Amor, el Auto de los Reyes Magos, el Liber Regum, el Fuero de Madrid, no ofrecen casos de le para tal función. Es curioso que este último texto no ofrezca ningún ejemplo de confusión; verbos que en él aparecen, tales como acoger, desonrar, enforcar, fallar, ferir, levar, matar, meter, vencer, que más tarde vacilarán en el uso de formas de dativo o de acusativo, presentan en el Fuero de Madrid, invariablemente, lo y los. Parece que, quien lo escribio, tenía aún claro sentido del uso etimológico. Quizá el leísmo personal había empezado ya a fraguarse, pues un texto como la Fazienda de Ultramar, unas centurias posterior, nos muestra el fenómeno en plena ebullición, pero, quien escribió el Fuero de Madrid, sabía utilizar correctamente las formas.

El primer texto que rompe, violentamente, la ausencia de le para objeto directo masculino singular de persona, es la Fazienda de Ultramar. El 23,25\% que ofrece para dicha función, supone un cambio brusco en la utilización de le y de lo. La evolución del leísmo personal ha debido ser grande en el espacio cronológico que media entre la redacción de los textos anteriores y la Fazienda. La diferencia existente entre el Liber Regum y la Fazienda resulta aún más llamativa si tenemos en cuenta que ambos textos tienen un mismo asunto: en los dos casos se trata de traducciones parciales de la Biblia. No debemos olvidar un factor que puede ser importante a la hora de explicar la diferencia en el tratamiento de $l o$ y $l e$ en estos dos textos, a saber, el factor geográfico. Es cierto que no sabemos con exactitud quién escribió la Fazienda de Ultramar, pero el carácter navarro-aragonés del Liber Regum no ofrece dudas. La afinidad linguística que haya podido observarse entre ambas 
obras ${ }^{74}$ queda en entredicho después del examen realizado sobre el uso de lo y le que estamos tratando ahora. En definitiva, quizá haya que ver una diferencia no sólo diatópica, sino también diastrática, en ambos textos, tal vez conjugable con el hecho de que, en las lenguas semíticas, la diferencia entre objeto directo y objeto indirecto es de construcción preposicional, no de variedades formales o propiamente morfológicas 75 .

Las obras de Gonzalo de Berceo registran casos de le y los porcentajes resultantes arrojan cifras más bien elevadas, aunque no tanto como las que arrojaba la Fazienda. La mayoría de los casos de le están utilizados, en Berceo, con verbos que cuentan con antecedentes latinos de construcción con dativo, por lo que su aparición en tales obras no ofrece el mismo carácter de confusión de funciones que la presentada por la Fazienda, pero indican la existencia de un portillo abierto a tal confusión. Esta se da, incluso, en el mismo Berceo, en algún caso ${ }^{76}$.

Por su parte, el porcentaje que el Libro de Apolonio nos muestra, en su reconstrucción original (reconstrucción que hace variar, respecto a su copia posterior, el porcentaje de $l o$ y le en virtud de la restitución de los casos de apócope, ya que los ejemplos de lo y le siguen siendo los mismos), se asemeja a las obras de Berceo en el empleo de $l e$.

De modo que el Fuero de Madrid, la Fazienda de Uttramar, las obras de Berceo, y el Libro de Apolonio parecen representar un momento ascensional del leísmo personal (que, en unos casos, responde a un uso etimológico, principalmente, en tanto que, en otros, se trata de una confusión total de formas y funciones), ascensión que culmina (tal como puede apreciarse en los porcentajes) en el manuscrito I-I-6 de la Biblia y en Poridat de Poridades. Ambos textos son claro ejemplo de la preferencia por la forma le para la función de objeto directo masculino singular de persona. Tal uso se ha extendido a la mayor parte de los verbos $\pi$, sin que responda a un factor de etimología. Y no sólo es total la confusión, sino que va más allá: existe, en estos textos, un empleo deliberado y consciente (o, al menos, reflejan un uso muy extendido) de la forma le para representar al objeto directo masculino. Este momento, a lo que parece, debió ser hacia comienzos de la segunda mitad del siglo xiII y alcanzó a la redacción de algunos fragmentos de la Primera Crónica General ${ }^{73}$. Es posible que estos hechos reflejen una

\footnotetext{
74 Tal afinidad la hemos encontrado apuntada por A. Y. DeYkrmond, en Historia de la Literatura espafiola, La Edad Media, I, Madrid, Ariel, 1973, pág. 149.

75 Agradezco esta observación a Francisco Marcos.

76 Cfr. nuestra tesis doctoral citada en la nota 73, I, págs. 58 y sig.

$\pi$ Ibidem, I, págs. 58 y sig.

73 Ibidem, I, págs. 58 y sig.
} 
preferencia, por parte de Alfonso $\mathrm{X}$, a utilizar la forma le. No lo sabemos. Las otras obras del monarca no nos aclaran demasiado las cosas, pues el Libro conplido ofrece poco lo y también poco $l e$, ya que sus preferencias van dirigidas a la apócope, tal como hemos explicado anteriormente. $Y$, en cuanto al Libro de açedrex, que, como veíamos, representa el momento en el que deja de utilizarse la apócope en favor de las formas plenas, ofrece un porcentaje bajo de le. Pero dicho porcentaje es engañoso y resulta de la agrupación de ejemplos en torno a unos pocos verbos, pues son 4 los verbos con los que se utiliza lo y 5 los utilizados con $l e^{\text {T. }}$.

La Historia Troyana se caracteriza por emplear lo de manera casi sistemática, rechazando el uso de le y de formas apocopadas. Al hablar de la apócope considerábamos este texto como ejemplo de la reacción contra el uso de la misma. Cabría caer en la tentación de pensar que tal reacción estuvo acompañada de la decisión de no utilizar, en lo que a las formas átonas tercera persona se refiere, el pronombre le para la función de objeto directo. De hecho, el apogeo de le para tal función, que observábamos en la Biblia y en Poridat de Poridades (así como en determinados fragmentos de la Primera Crónica General) no vuelve a encontrarse en ningún otro texto. En tal caso, podría pensarse, no ya que Alfonso $\mathrm{X}$ era partidario de la forma le (tal como hemos apuntado más arriba), sino que, caso de haberlo sido durante algún tiempo, reaccionó en contra de su empleo, de la misma manera que lo hizo contra la apócope.

Por otra parte, no sabemos cuál fue la proporción original de lo y le en el Libro de Alexandre. Tanto el manuscrito $« \mathrm{O}$ » como el $« \mathrm{P} \star$ ofrecen cifras muy altas para lo. Tampoco podemos saber qué sucedio con el Libro de Apolonio. Lo que sí podemos observar es que, respecto al texto original, $l o$ se ha visto favorecido tanto como $l e$ por el descenso de la apócope. Otro tanto sucede con el Libro de la Infancia y Muerte, que coincide en cifras con la Historia Troyana, Libro de Alexandre, Elena y María y Libro de Apolonio, pero no podemos saber si tales cifras se deben a la fecha de copia o de composición de los textos. El mismo problema ofrece la Vida de Santa Maria Egipciaca. Por su parte, los ejemplos recogidos en los Documentos Lingüisticos de España, que podrían resultarnos valiosísimos, ofrecen pocos ejemplos de $l o$ y le para objeto directo masculino singular de persona. Pero algo pueden aportar, ya que, aunque pocos, su distribución no deja de ser significativa: 3 casos de $t o$ corresponden al año 1223 , el único caso de le está

To Ibidem, I, págs. 58 y sig. 
localizado en Castilla del Norte en el año 1244, y de nuevo encontramos formas de 10 , pero todas ellas posteriores a $1288^{\circ}$. Estos ejemplos, si bien son pocos para apoyar lo dicho en páginas anteriores, tampoco lo contradicen, por otra parte.

No podemos dejar de señalar un hecho que tiene su importancia a la hora de relacionar unos fenómenos con otros, y es el siguiente: hemos visto, en páginas anteriores, cómo los porcentajes de apócope resultaban especialmente altos en algunos textos tales como la Biblia, Libro conplido, Libro de açedrex y Poridat, y que, por decisión de Alfonso $\mathrm{X}$, según parece, comenzó a declinar su uso. Pues bien, debemos señalar ahora que es precisamente en los textos en que los porcentajes de apócope son mayores, donde también es más acentuado el leísmo personal en singular. Parece que el empleo de apócope y la frecuencia mayor de le para objeto directo son fenómenos paralelos. Claro que, esto no indica un uso exclusivo de $l e$ en tales textos, como pretendía Cuervo ${ }^{81}$, pero sí una cierta proclividad al empleo de le allí donde la apócope es más frecuente. Es posible que el gran uso de apócope favoreciese el hecho de que, al restituir las formas plenas en determinados casos (pero en el momento mismo de auge, no después) dicha restitución se hiciese mediante $l e$, apoyado esto por el hecho de que los pronombres apocopados ' $m^{\prime}, t^{\prime} s^{\prime}$ se restituían por $m e, t e, s e$, respectivamente. Sin embargo, ya hemos visto que la distinción debió subsistir mentalmente, pues, pasada la época de auge de la apócope, disminuyó, al mismo tiempo, el leísmo de persona, restableciéndose el uso de lo para objeto directo masculino.

2.2.2. Analisis de porcentajes de objeto directo masculino plural:

\begin{tabular}{|c|c|c|c|c|c|c|}
\hline \multirow{3}{*}{$\begin{array}{l}\text { Fuero de Valfermoso de las Monjas } \\
\text { Fuero de Madrid }\end{array}$} & \multicolumn{3}{|c|}{ LOS } & \multicolumn{3}{|c|}{ LES } \\
\hline & & asos & $(0 \%)$ & & asos & $(0 \%)$ \\
\hline & 6 & 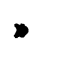 & $(100 \%)$ & $\mathbf{0}$ & 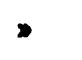 & $(0 \%)$ \\
\hline Los Diez Mandamientos & 2 & 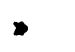 & $(100 \%)$ & $\mathbf{0}$ & $\star$ & $(0 \%)$ \\
\hline Razón de Amor & $\mathbf{0}$ & 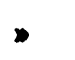 & (0\%) & $\mathbf{0}$ & $\star$ & $(0 \%)$ \\
\hline Liber Regum & 17 & • & $(100 \%)$ & 0 & $\star$ & $(0 \%)$ \\
\hline Auto de los Reyes Magos & $\mathbf{0}$ & $\bowtie$ & $(0 \%)$ & $\mathbf{0}$ & 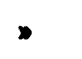 & $(0 \%)$ \\
\hline La Fazienda de Ultramar & 211 & » & $(92,13 \%)$ & 18 & » & $(7,86 \%)$ \\
\hline La Vida de San Millán & 27 & • & $(93,1 \%)$ & 2 & $\star$ & $(6,89 \%)$ \\
\hline La Vida de Santo Domingo & 28 & • & $(87,5 \%)$ & 4 & $\star$ & $(12,5 \%)$ \\
\hline El Duelo de la Virgen & 8 & & $(72,72 \%)$ & 3 & • & $(27,27 \%)$ \\
\hline Loores de Nuestra Señora & 8 & • & $(100 \%)$ & 0 & • & $(0 \%)$ \\
\hline
\end{tabular}

o Ibidem, II, págs. 327 y sig.

81 Cfr. Rutino José Cukrvo, «Los casos», pág. 243. 


Los Signos
Milagros de Nuestra Señora
Evangelio de San Mateo
Evangelio de San Marcos
Evangelio de San Lucas
Evangelio de San Juan
Hechos de los Apóstoles
Epistolas
Apocalipsis
Libro conplido
Libro de açedrex
Poridat de Poridades
Fuero de Alba de Tormes
Libro de Alexandre (ms. «O»)
Elena y Maria
Roncesvalles
Historia Troyana
Fuero de Teruel
Libro de Apolonio
Vida de Santa Maria Egipciaca
Libro de la Infancia y Muerte
Libro de Alexandre (ms. «P»)

\begin{tabular}{|c|c|c|c|c|c|}
\hline \multicolumn{3}{|c|}{ LOS } & \multicolumn{3}{|c|}{ LES } \\
\hline & asos & $(100 \%)$ & & asos & $(0 \%)$ \\
\hline 16 & > & $(80 \%)$ & 4 & • & $(20 \%)$ \\
\hline 47 & $\star$ & $(100 \%)$ & 0 & 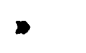 & $(0 \%)$ \\
\hline 30 & $\star$ & (75\%) & 10 & 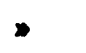 & $(25 \%)$ \\
\hline 46 & 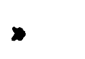 & $(83,63 \%)$ & 9 & • & $(16,36 \%)$ \\
\hline 12 & 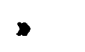 & $(80 \%)$ & 3 & 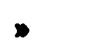 & (20\%) \\
\hline 77 & 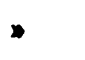 & $(84,61 \%)$ & 14 & • & $(15,3896)$ \\
\hline 29 & 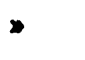 & $(93,54 \%)$ & 2 & 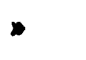 & $(6,45 \%)$ \\
\hline 19 & 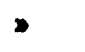 & (95\%) & 1 & 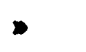 & (5\%) \\
\hline 64 & 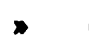 & $(62,12 \%)$ & 39 & 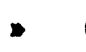 & $(37,86 \%)$ \\
\hline 16 & • & $(84,21 \%)$ & 3 & $\bullet$ & $(15,78 \%)$ \\
\hline 20 & $\star$ & $(95,23 \%)$ & 1 & $\star$ & $(4,76 \%)$ \\
\hline 29 & $\triangleright$ & $(93,54 \%)$ & 2 & > & $(6,45 \%)$ \\
\hline 167 & - & $(88,82 \%)$ & 21 & 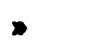 & $(11,17 \%)$ \\
\hline 0 & 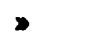 & $(0 \%)$ & 0 & - & (0\%) \\
\hline 0 & 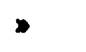 & $(0 \%)$ & 0 & $\star$ & $(0 \%)$ \\
\hline 135 & $\bullet$ & $(83,3 \%)$ & 27 & 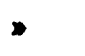 & $(16,6 \%)$ \\
\hline 30 & 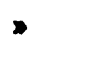 & $(85,71 \%)$ & 5 & $\bowtie$ & $(14,28 \%)$ \\
\hline 15 & 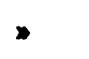 & $(78,94 \%)$ & 4 & & $(21,05 \%)$ \\
\hline 24 & $\star$ & $(92,30 \%)$ & 2 & $\bullet$ & $(7,69 \%)$ \\
\hline 15 & 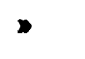 & $(100 \%)$ & 0 & • & $(0 \%)$ \\
\hline 197 & $\star$ & $(94,71 \%)$ & 11 & 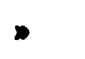 & $(5,28 \%)$ \\
\hline
\end{tabular}

Lo primero que salta a la vista, al examinar estos porcentajes, es la ausencia de les en los textos más tempranos. Ningún caso de les ofrece el Fuero de Madrid; Los Diez Mandamientos y el Liber Regum, tampoco. La aparición de les corresponde a la Fazienda de Ultramar, lo cual no nos extraña, dado que este texto se muestra absolutamente progresista en todo lo referente al empleo de los pronombres átonos de tercera persona. Pero observamos que el porcentaje es muy inferior al que dicho texto arrojaba para le en función de objeto directo. En cambio, las obras de Berceo ofrecen porcentajes algo superiores a los ofrecidos en singular ${ }^{82}$. El manuscrito I-I-6 de la Biblia presenta porcentajes bastante parecidos a los de las obras de Berceo, pero los verbos con los que está empleada la forma les no cuentan con antecedentes latinos de construcción con dativo ${ }^{83}$.

El texto que mayor porcentaje de les ofrece para objeto directo es El Libro conplido. Esto es importante, pues también es el texto que

\footnotetext{
82 La mayorfa de ellos, sin embargo, responden a un uso latino. Cfr. nuestra tesis doctoral citada en la nota 73 , I, págs. 53 y sig.

83 Ibidem, I, págs. 53 y sig.

LXI. -10
} 
presentaba el porcentaje más elevado de apócope. Podría pensarse que el empleo de apócope, única forma para objeto directo en singular, favorecía la confusión de formas en plural. De hecho, los porcentajes más altos de les corresponden a los textos que, a su vez, tienen mayor porcentaje de apócope. Pero, claro está, son también, precisamente, los textos más leístas en singular. En cualquier caso, ello parece indicar una cierta relación entre el leísmo y el uso de apócope, hecho que ya hemos destacado en el apartado correspondiente al leísmo de persona en singular.

En todos los textos, salvo en El Libro conplido, los tiene un porcentaje considerablemente mayor al de les y, al mismo tiempo, en todos ellos son más los verbos que se construyen con los que con les. Los dos manuscritos, «O» $\mathrm{y}$ « $\mathrm{P}$, del Libro de Alexandre, ofrecen 12 y 13 verbos, respectivamente, construidos con les, pero los construidos con los son 90 y 102, por lo que la relación a favor de los casos de los está perfecta. mente mantenida ${ }^{84}$.

A diferencia de lo que hemos podido observar en páginas anteriores, al tratar del leísmo personal en singular, no encontramos, en plural, un momento de especial auge del leísmo, sino que éste se muestra como un fenómeno que evoluciona lenta y progresivamente, arrastrado, seguramente, por el singular. Ya ha sido señalado por Rafael Lapesa que «desde los textos más viejos el leísmo es mucho menos intenso en plural que en singular» ${ }^{85}$. De cualquier manera, les gana algún terreno, aunque lentamente, y mantiene sus porcentajes sin presentar disminuciones posteriores. Esto está de acuerdo con los cómputos hechos por Cuervo para diversas épocas ${ }^{86}$, así como con los hechos por Keniston para el siglo $\mathrm{XvI}^{87} \mathrm{e}$, incluso, con los recuentos llevados a cabo por Salvador Fernández Ramírez en autores contemporáneos ${ }^{88}$.

Por último, en cuanto a los verbos en torno a los cuales está centrada la vacilación de formas de acusativo y de dativo, hemos podido observar que un núcleo considerable de ellos cuenta con antecedentes latinos de construcción con dativo ${ }^{*}$. Tales verbos han sido señalados

84 Ibidem, I, págs. 53 y sig.

85 Cfr. RafaEt LaPESA, «Sobre los orígenes», pág. 539.

\& Cfr. Rufino José Cuervo, «Los casos», pág. 109. Es curioso sefialar que la única excepción la constituye un alavés, Pero López de Ayala. ¿Tendrá relación con los porcentajes relativamente altos ofrecidos por el riojano Gonzalo de Berceo?

87 Cfr. Keniston, The Syntax of Castilian Prose. The sixteen century, Chicago, Chicago Univ. Press, 1937, 7.133, 7.16.

B Cfr. Salvador Fernandez Ramfrez, Gramática española, Madrid, Revista de Occidente, 1951, págs. 182-212.

89 Cfr. Nuestra tesis doctoral citada en nota 73, I, pág. 115. 
ya por Rafael Lapesa ${ }^{20}$ y nosotros no hacemos aquí más que constatar y ampliar la lista, que cuenta con verbos tales como bendezir, convidar, maldezir, obedecer, socorrer, amenazar, ayudar, nozir, servir, uviar. Aparte de estos verbos, existe un buen número de ellos para los cuales no hemos encontrado antecedentes latinos de construcción con dativo. Son los verbos adorar, aduzir, alcanzar, amar, amparar (des-), apedrear, babtizar, buscar, catar, cercar, coger, combater, cometer, conoçer, conortar, criar, cuytar, dar, denostar, desbaratar, dexar, echar, enbiar, enterrar (so-), escarnir (-ecer), esperar, fallar, ferir, guardar, guiar, levantar, levar, matar, meter, mover, poner, prender, quemar, tomar, traer, vencer, ver. Vemos, pues, hasta qué punto el área del objeto directo personal está invadida, en los primeros siglos de la lengua, por el contagio de la forma de dativo de verbos que en latín lo regían.

Ha habido un intento, por parte de W. B. Brewer, de pretender explicar el diferente uso de $l e$ y $l o$ con unos y otros verbos mediante su clasificación semántica en verbos «de tendencia» y verbos «de efecto»" Con tal clasificación intenta Brewer diferenciar entre verbos que denotan un proceso activo (afficient verbs) y aquellos que describen algo que se realiza plenamente (effective verbs), de tal manera que habría una preferencia por parte de los verbos ade tendencia» a la utilización de las formas de acusativo, en tanto que los «de efecto tenderían al empleo de las formas de dativo. Esta clasificación, relacionada, en cierto modo, con la diferencia verbal entre aspecto perfectivo e imperfectivo, no deja de ser sugestiva. Pero quizá su aplicación tenga más fortuna en un estudio de tipo sincrónico que histórico (lo cual no significa, por nuestra parte, una separación de sincronía y diacronía, sino que únicamente pretendemos sugerir que, tal vez, la lengua ha llegado a fijar el uso de le y $l o$ de acuerdo con unos criterios que nada tienen que ver con la situación primitiva). En efecto, Brewer presenta una lista de unos y otros verbos, de tal manera que verbos «de tendencia» serían acorrer, amparar (des-), apremiar, ayudar, conortar, estorvar, nozir, onrar, servir, y verbos «de efecto» aduzir, afogar, derribar, fallar, enviar, ferir, meter, mover, recebir, tomar, traer, y corresponderían, a los del primer grupo, formas de dativo, $y$, a los del segundo, de acusativo. $Y$, cuando un verbo clasificado normalmente como «de efecto», lleva un pronombre dativo, lo explica por el hecho de que, en ese contexto determinado, está em-

90 Cfr. Rafael LaPESA, «Sobre los orígenes», págs. 528-531.

91 Cfr. W. B. BREWER, «Extent of verbal influence and choice between «Le» and «Lo» in alphonsine prose», Hispanic Review, XXXVIII, 1970, págs. 133-146. Con los términos ade tendencia y ade efecto intentamos traducir la oposición entre afficient verbs y effective verbs. 
pleado como verbo «de tendencia». Así, pone el ejemplo del verbo tener, que normalmente es ade efecto», pero que presenta forma de dativo en aquellas ocasiones en las que denota un proceso activo, como en el ejemplo alfonsí «fincaron en so otero que auien tomado et touieron le» 2 . En cambio, cuando nosotros acudimos a los ejemplos que hemos recopilado, nos encontramos con que, en verbos que hemos observado por nuestra cuenta, así como en otros clasificados por Brewer, el empleo de formas de dativo y de acusativo vacila en contextos que nada tienen que ver con las puntualizaciones anteriores. Veamos algunos de ellos:

- Comendo Josep los metges que lo enbalsamassen a so padre e enbalsamaron lo* (Fazienda de Ultramar, pág. 60) / «Enbalsamaronle e fue metido en un athaut en Egypto» (Ibidem, pág. 61); *Andat e matemosle [a José], echemosle en aquel pozo» (Ibidem, pág. 51) / «E echaron suertes, e cayo la suert a Jonas, e echaronlo en la mar» (Ibidem, pág. 119); «Crescio el ninno e aduxolo a la fija de Pharaon* (Ibidem, pág. 62) / «Dixo Samuel: «Adozidme ad Arag, el rey d'Amalech». Aduxixieronle gruesso e tremblant» (Ibidem, pág. 107); $\ltimes \mathrm{E}$ tantol dixeron sos omnes que prisieron a Daniel e metieronto en el pozo de los leones» (Ibidem, pág. 179) / «Por esto prisieron a Daniel los de Babilonia e metieronle en el pozo de los leones* (Ibidem, pág. 184); «Enfeuçatvos en el rey de Siria e servidlo e salvarnos a* (Ibidem, pág. 154) / «Agora temet al Criador e servitle con tod coraçon» (Ibidem, pág. 101).

Se habrá observado que todos los ejemplos pertenecen a un mismo texto, la Fazienda de Ultramar, hecho que ha sido intencionado por nuestra parte para que resulte más patente lo que intentamos resaltar aquí. Pero no son únicos estos casos. La vacilación en un mismo contexto, en un mismo texto y con un mismo verbo, es un hecho frecuente en los datos que hemos obtenido ${ }^{93}$ y podrían multiplicarse indefinidamente. Creemos que son suficientes y claros los que hemos elegido para hacer ver que, en los primeros siglos de la lengua, la vacilación en el uso de unas y otras formas (acusativo o dativo), parece estar más de acuerdo con factores debidos a la continuación de usos etimológicos, como primera etapa, y contagio a casos en los que tales usos etimológicos no se daban. Es posible, insistimos, que, en el uso actual, la distinción hecha por Brewer tenga alguna realidad, y que esa realidad se haya venido perfilando a través de los siglos. Lo que nosotros queremos decir es que, en nuestros datos, no hemos encontrado apoyo a tal teoría.

9 Ibidem, pág. 144.

93 Cfr. nuestra tesis doctoral citada en nota 73 , tomo II. 


\subsection{SUSTITUCión DEL acusativo LATINO POR EL DATIVO EN DETERMiNadas CONSTRUCCIONES.}

2.3.1. Sujeto de infinitivo $u$ oración subordinados que hacen papel de objeto directo.

En latín, este sujeto iba, generalmente, en acusativo, aunque ya desde Tácito hay casos de JUBERE con dativo ${ }^{24}$. De ahí que, en los textos más antiguos, nos encontremos con las formas $l e, l i$, les, lis para representarlos. En la Fazienda de Ultramar aparecen ya ejemplos con el pronombre dativo, y no sólo con el verbo mandar, sino extendidos a otros verbos causativos como fazer y dexar (véase más adelante). Cuervo señaló que la forma de dativo se habría aplicado, en un principio, a aquellos casos en los que el verbo subordinado llevaba objeto directo 95 ; la sustitución de la forma de acusativo por la de dativo se habría incrementado en estos casos. Nosotros hemos recogido, en los textos estudiados, 59 casos, que presentan, ya, forma de dativo. De estos 59 casos, 40 corresponden a ejemplos en los que el verbo subordinado lleva objeto directo, por lo que la afirmación de Cuervo se confirma en nuestros datos. Los ejemplos concretos son los que siguen:

«fazle entender aquella visión» (Fazienda de Ultramar, pág. 182); «E mandoles poner grandes piedras a la boca de la cueva do eran ascondidos» (Ibidem, pág. 101); «e dixoles que pidiessen mercet a Dios e que les fiziesse saber esta poridat» (Ibidem, pág. 175); «Si tu no li mandares decir la missa mia [al capellano]» (Milagros, 253, pág. 92); «Mandolis que li diessen todos los malfechores» (Santo Domingo, 742, pág. 94); «Fizieron le traer la cruz [a él]» (Evangelio de San Marcos, 21, pág. 94); «e dexaron les aduzir el pollino ${ }^{6}$ " (Ibidem, 6, pág. 86); «e mandoles que non troxiessen por la carrera fueras blago» (Ibidem, 8, pág. 76); «e fizieron le traer la cruz* (Evangelio de San Lucas, 26, pág. 147); «e fazie les entender todas las escripturas que del eran» (Ibidem, 27, pág. 149); «El mando les que lo non dixiessen a nadi (Ibidem, 21, pág. 119); «e mandoles que lo non dixiessen a ninguno» (Ibidem, 21, pág. 119); «E fiz les seruir a la caualleria del cielo» (Hechos, 42, pág. 205); «punnauan en fazer les tener los carnales mandamientos» (Epistolas, pág. 346); qque les mandara guardar los carnales mandamientos» (Ibidem, 25, pág. 391); *E si las fortunas fueren, fazerles-an fazer bien* (El Libro conplido, 5, pág. 183); "...mandoles el rey quel aduxiesse ende cadauno muestra de prueua» (Libro de açedrex, 28, págr. 6); «fizieron le creer que lo querien

\footnotetext{
94 Señalado por RAFAEL LAPESA, en «Sobre los orfgenes», pág. 535.

95 Cfr. Rufino José CuRRvo, nota 121 a la Gramática de ANDrés Bello.

* Todos los ejemplos van referidos a antecedente masculino personal, cuando no se indique otra cosa.
} 
matar (Alexandre «O», 1092, pág. 331); «fizoles cuemo era la cosa entender (Ibidem, 567, pág. 105); *Faziales la grant coyta el miedo oluidar (Ibidem, 2159, pág. 375); «mandoles que touiessen su ley a derechas» (Ibidem, 1144, pág. 204); «Estonçe fezieronle todos entender que...* (Historia Troyana, 20, pág. 96); «E esto les fizo demandar treguas por fuerça» (Ibidem, 8, pág. 119); «...fezieron les dexar el campo (Ibidem, 29, página 33); «e fágale mondar carrera» (Fuero de Teruel, pág. 137); "Fizo le entender toda su voluntad» (Apolonio, 373, pág. 44); Mando les que comprassen conducho» (Ibidem, 459, pág. 54); «Fizo les entender el rey auenturado commo auie el reyno assu yerno mandado» (Ibidem, 617, pág. 72); «Después les mandaba fer oración» (Santa María Egipciaca, v. 837); «Fisieron le creer al rrey grant falsedat» (Alexandre «P», 1970, pág. 342); «yo le faré leuar el gato de aqui al rrio» (Ibidem, 1290, pág. 228); *Fisieron le creer que lo querian matar* (Ibidem, 1902, pág. 330); «fisoles fazer luego cartas» (Ibidem, 308, pág. 60); «Fisieron les tornar las cuestas sin gradiello (Ibidem, 632, pág. 114); «Fisoles commo era la cosa entender (Ibidem, 567, pág. 104); «Fasieles la grat cueyta el miedo oluidar» (Ibidem, 2159, pág. 374).

Cuervo consideraba asimismo que, a partir de la sustitución del pronombre acusativo por el de dativo, en estos casos, la forma de dativo se habría extendido a aquellos otros en los que el verbo subordinado, siendo transitivo, no llevaba objeto directo $"$. En este caso se hallan 3 de los ejemplos recogidos, que representarían la fase de transición:

* Rogar non le dexaron» (Santo Domingo, 117, pág. 15); «e faziales mucho amenudo razonar sobre los fechos que nascien delas cosas» (Libro de açedrex, 10, pág. 6); «E los de la colación le fagan iurar» (Fuero de Alba de Tormes, 30, pág. 330).

Los 16 ejemplos restantes que ofrecen pronombre dativo corresponden a casos en los que el verbo subordinado es intransitivo. Para Cuervo, este pronombre dativo se explicaría por contagio con los casos en los que el verbo subordinado es transitivo, contagio progresivo según las dos fases que acabamos de analizar. Pero tales casos se remontan a la Fazienda de Ultramar, de modo que el cambio está registrado desde los textos más antiguos.

Por otra parte, Cuervo afirmaba que el dativo es de rigor cuando el verbo subordinado lleva objeto directo ${ }^{8}$. Esto puede servir de regla general, pero hay excepciones, pues nosotros hemos encontrado casos en los que el pronombre empleado es el de acusativo, pese a ser transitivo el verbo subordinado y llevar objeto directo:

97 Cfr. Rufino José Cuervo, nota 121 a la Gramática de ANDrés Bello.

7 Cfr. Ibidem, y también «Los casos», págs. 239-240. 
«et que los manda bien pagar de lo que compraren et de lo que uendieren» (Poridat de Poridades, 5, pág. 38); «...que sol no los dexaua las cabeças sacar» (Alexandre «O», 1097, pág. 197); «no los dexa el miedo su derecho complir» (Ibidem, 2077, pág. 361).

No creemos que se trate del acusativo latino mantenido, ya que los textos que presentan los ejemplos no son de los más antiguos ${ }^{99}$, así como tampoco se trata de textos caracterizados por un uso arcaizante de los pronombres átonos de tercera persona. Por otra parte, observamos que son casos de plural todos ellos. Es curioso que aquellos ejemplos en los que el verbo subordinado, siendo transitivo y llevando objeto directo, presenta forma de dativo, sean también, en su mayoría, casos de plural. Y es, asimismo, notable, que los casos de plural aparezcan en los textos más antiguos, mientras que los de singular, además de ser menos numerosos, aparecen preferentemente en textos más tardíos. Esto nos lleva a pensar que los ejemplos de los pueden estar relacionados con otro fenómeno cuya preferencia a manifestarse en plural es también clara: el loísmo. Y puede tener relación, a su vez, con el hecho de que también prefiera el plural la conservación (etimológica) de la forma de acusativo en casos en los que el latín regía doble acusativo. Seguramente, la preferencia por el plural en estos tres fenómenos es indicio de la tímida pugna por fundir en una sola la categoría de masculino (tanto de persona como de cosa) en favor de los (téngase en cuenta que, en plural, no existe la categoría de neutro). Pero tal hecho no pasó de ser un tímido intento, que no cuajó, seguramente porque, al intentar establecer un paradigma que tuviera los para masculino plural (una vez fundidas las categorías de objeto directo e indirecto, por un lado, y las de persona y cosa, por otro) no encontró el mismo correlato en el femenino, que usó siempre las para objeto directo, al tiempo que mantenía les para el objeto indirecto con casi absoluta exclusividad ${ }^{100}$.

99 Aunque, desde luego, un hecho lingüístico puede permanecer en estado de aactividad latente», pudiendo pasar inadvertido durante siglos y sin registrarse en los textos, por razones socio-linguísticas o de otra índole, como ya puso de manifiesto RAMÓN MENÉNDEZ PIDAL en "Modo de obrar el sustrato lingǘrstico», $R F E$, tomo XXXIV, 1950. Pero creemos que no es éste el caso.

100 Esta exclusividad se refiere a los primeros siglos de la lengua, pues, posteriormente, el laísmo se convertirá en uso predominante en escritores madrileños. Cfr. Rufino José CuRrvo, «Los casos», pág. 111; Emilio Cotarelo, Sobre el «le» y «la». Cuestión gramatical, Madrid, 1910, págs. 21-124; KRNISTON, ob. cit., 7.32; Salvador Fernández Ramtrez, Gramática española, págs. 201-203, y Rafael LAPESA, ob. cit., págs. 544-546. 


\subsubsection{Construcciones con verbos que en latin regian doble acusativo.}

El doble régimen directo de algunos verbos latinos como ROGARE, INTERROGARE, POSCERE, DOCERE, se mantuvo durante algún tiempo en construcciones romances ${ }^{101}$. Poco a poco, el primitivo acusativo de persona fue sentido como objeto indirecto, tomando forma de dativo. Nosotros hemos registrado ejemplos del mantenimiento de este doble acusativo en varios de los textos estudiados:

«E los prophetas amonestavanlos la ley del Criador e no los querian creer (Fazienda de Ultramar, pág. 158); «E preguntola cuya fija era» (Ibidem, pág. 47); «rogólo que rezasse por ella el psalterio» (San Millán, 178, pág. 113); «Rogaronlos que fuessen» (Ibidem, 352, pági. 138); «Tornó e preguntólos quántos podrien seer» (Ibidem, 164, pág. 111); «E castigolos que lo non dixiessen a ningunow (Evangelio de San Marcos, 36, pág. 79); «E preguntauan los: ¿Que yuades fablando por la carrera?» (Ibidem, 32, pág. 83); «e castigaua las que souiessen en paz» (Hechos, 26, pág. 205); a...e castigandolos que souiessen en la fe» (Ibidem, 20, pág. 220); «Rogaua los que al otro sabado les dixiessen estas palauras» (Ibidem, 42, pág. 218); «rogauan los que saliessen de la ciudat» (Ibidem, 39, pág. 224); «amonesta los cuemo sean de buenas costumbres» (Epistolas, pág. 294); «amonesta los que tornen a paz» (Ibidem, pág. 248); «Amonesta los que por prophecia... no se quiten de la fe de Christo» (Ibidem, pág. 347); «rogo los quel dexassen / mas nol nol ualio nada» (Alexandre «O», 621, pág. 114); «rogola que lle diesse / de temprano ceuada» (Ibidem, 2452, pág. 423); «començaronlo a rrogar e a falagar que dexasse aquella yda (Historia Troyana); *...e quisiera lo don Hector leuar consigo a Troya por lo mostrar el su grand linage» (Ibidem, 16, pág. 48); «rogola que diesse temprano çivada» (Alexandre «P», 2452, pág. 422).

Este último ejemplo aparece en los dos manuscritos del Libro de Alexandre, por lo que podemos pensar que se encontraba en el manuscrito original. Los ejemplos recogidos son, de todos modos, minoritarios, ya que lo normal es que el acusativo de persona haya sido sustituido por la forma de dativo. Así, en la Fazienda de Ultramar, junto a los dos acusativos mantenidos, hay 10 casos de dativo; en el manuscrito I-I-6 de la Biblia, frente a los 10 casos de acusativo, hay 42 casos de dativo; en el Libro de Alexandre hay 18 casos de dativo y tan sólo 2 de acusativo; en la Historia Troyana, los casos de acusativo son 2, y 17 los de dativo. Estos acusativos son, pues, un resto latino que desaparece ante el empuje del dativo. Creemos que su perduración (etimológica) pudo ser uno de los factores que favorecieron el lósmo antietimológico. La Fazienda, la Biblia (manuscrito $\mathrm{E}_{6}$ ) y el Libro de Alexandre, son, pre-

101 Cfr. Rapael Lapbsa, ob. cit., pág. 536. 
cisamente, textos en los que hemos podido recoger casos de loísmo antietimológico. Es una coincidencia que debe ser tenida en cuenta. Por otra parte, vemos que, de los 18 ejemplos que hemos recogido de doble acusativo mantenido, 13 son casos de plural, frente a los 6 que ofrece el singular. Esta preferencia a aparecer en plural es característica, asimismo, del loísmo, como veremos más adelante. De modo que, ya desde ahora, apuntamos esta relación que existe entre los dos fenómenos.

\subsubsection{Construcciones con objeto directo y complemento predicativo} referente a él.

Ya ha apuntado Rafael Lapesa ${ }^{102}$, que, en este tipo de construcciones, el acusativo pronominal se sustituye, desde muy pronto, con un dativo. Nosotros hemos encontrado ejemplos de esta sustitución desde el Liber Regum, por lo que corroboramos que, en efecto, se trata de un fenómeno muy antiguo. Los casos que hemos registrado, con pronombre dativo, son los que siguen:

*...e por esto le dixieron el rei don Garcia el trembloso* (Liber Regum, pág. 36); «e dizenle Acheldemach» (Fazienda, pág. 205); «Dizenle agora: el Carnero del leon» (Ibidem, pág. 205); ae dizenle 'deus muscarum'» (Ibidem, pág. 123); «e dizenle Dan» (Ibidem, pág. 115); «e dizenle el Flum del Diable e Mar Muerto» (Ibidem, pág. 45); ae dizenle 'el mar Tyberiades'» (Ibidem, pág. 112); «Por esto les dizen Samaritanos» (Ibidem, página 135); "Al enfermo por nomne / dicienli Armentero" (San Millan, 127, pág. 105); «Façerle degannero» (Santo Domingo, 115, pág. 15); «Fiço le Dios por end en çielo parçionero» (Ibidem, 26, pág. 4); a...diçienli HERMANO) (Ibidem, 191, pág. 24); «Jerónimo li dizen a ese clavero» (Milagros, 309, pág. 112); «Dizienli Ildefonso» (Ibidem, 49, pág. 46); «Colgava delant ella un buen aventadero / en el seglar lenguage dízenli moscadero» (Ibidem, 321, pág. 115); „Clamavanlis los omnes traidores provados» (Ibidem, 728, pág. 892); «La gloriosa Maria, madre de Ihesu Christo, ouo el padre de Nazareth e dixieron le Ioachin» (Evangelio de San Mateo, 207a, 4, pág. 21); « Ay de uos, maestros e phariseos ypocritas! que cerrades el mar e la tierra por que fagades uno desterrar; e quando fuere fecho, fazedes le fiio del infierno en doblo de uos* (Ibidem, 221a, 15, pág. 61); «El mismo Dauid le llama Sennor» (Evangelio de San Marcos, 37, pág. 89); *...e fazer le rey» (Evangelio de San Juan, 15, pág. 161); «En Iherusalem fazien fiestas del edificamiento del tempo, e dizen les Encenias, e era yuierno» (Ibidem, 22, pág. 171); «E dos dellos aquel mismo dia yuan a un castiello que era luenne de Iherusalem sessenta estados, e dizien le Emaus» (Evangelio de San Lucas, 13, pár. 148); «...e dizen te Tito» (Hechos, 7, pág. 226); «Quando el enpuxo a la puerta, salio una

10 Cfr. Ibidem, pág. 537. 
moça a ueer que era, e dizien le Roda» (Ibidem, 13, pág. 215); ¿E en el catamiento quando la planeta passa a la planeta por un grado, dizen-le quitamiento; que ya se quito d'ella» (El Libro conplido, 41, pág. 23); «Cada dos grados que sea so alongamiento de la cabeça de Aries egual miente a diestro e a siniestro, dizienles los dos grados eguales en poder (Ibidem, 12, pág. 23); «...dizenle iuego de donzellas» (Libro de açedrex, 26, pág. 26); "Otro alquerque ha y que llaman el de tres e dizenle assi porque se iuega con seys trebeios» (Ibidem, 6, pág. 370); «E como quiere que esso se torne en uso e en pro de fecho de armas por que non es esso mismo, llaman le iuego» (Ibidem, 11, pág. 4); «E cabo dell en la otra casa de medio, esta otro trebeio que es a semeiança del alfferez, que tiene la senna de las sennales del rey, e algrunos omnes a, que non saben el nombre, e llaman le alfferza» (Ibidem, 30, pág. 12); «E por esta fuerça que dixiemos, le llaman iuego forçado (Ibidem, 24, pág. 26); «El segundo iuego es que se doblan las casas e llaman le 'doze hermanos' o 'doze canes' (Ibidem, 10, pág. 310); *...e llaman le iuego de cercar la liebre» (Ibidem, 33, pág. 364); "Sollien lle Alexe / de primero llamar (Alexandre «O», 360, pág. 69); «Calectrix le dixioron / desque fue pequenina (Ibidem, 1863, pág. 324); «Trayçion le dixioron / luego bien de chiquiella» (Ibidem, 2455, pág. 423); «la muger de Ector / Androna le dezien» (Ibidem, 569, pág. 105); «que les dezien ebreos» (Ibidem, 1165, pág. 208); «por nombre 'lles dizen / Pallas venus e Iunio» (Ibidem, 340, pág. 67); «La muger de don Etor / Madrona le disian» (Alexandre «P», 569, pág. 104); «que les disien ebreios» (Ibidem, 1165, pág. 208); «por nombre les disen Venus Palas e Juno» (Ibidem, 340, pág. 66).

El pronombre dativo está registrado antes, en esta construcción, que para el sujeto de infinitivo $u$ oración subordinados que hacen papel de objeto directo. Incluso un texto conservador como el Liber Regum ofrece un caso de pronombre dativo. También Berceo los ofrece, lo que corrobora la antiguiedad del fenómeno. No nos extraña que la Fazienda, progresista en todo lo que concierne a la utilización de los pronombres átonos de tercera persona, registre formas de dativo, pero observamos que, en dicho texto, aparecen ya extendidas, incluso, a casos referidos a antecedente de cosa. El total de ejemplos registrados es de 72 singulares, frente a 17 plurales. En singular, a su vez, hay $37 l o$ y $35 l e$; en plural, 9 los y 8 les. Parece, pues, que la proporción es semejante; la única diferencia estriba en que el singular arroja más casos.

\subsection{LEISMO DE COSA (MASCULINO).}

Frente a la gran extensión del leísmo personal, tal como hemos visto en los textos estudiados, el leísmo de cosa ofrece un desarrollo menor, aunque no tan minoritario como el loísmo o el leísmo para persona femenina. Los ejemplos que hemos podido reunir son los siguientes: 
"Vees este fonsado tan grand? Dios le dara en tu mano" (Fazienda, pág. 127); «El arbol que tan era e echavanle en tierra... (Ibidem, pág. 178); «Estonz trobaron i. libro en el tiemplo e leyeronle delant el pueblo» (Ibidem, pág. 15); «...e todo se menuzava como el polvo de la tierra que le lieva el viento en estiu» (Ibidem, pág. 175); «Prendet el ençensario e ponetle sobre el ara, e meted y encienso (Ibidem, pág. 86); «Fita es un Castiello fuert \& apoderado; / infito \& agudo, en fondon bien poblado, / el buen rey don Alfonso le tenie amandado, / el que [fo] ${ }^{103}$ de Toledo, si non so trascordado" (Santo Domingo, 733, pág. 87); "Yo puedo destruir este templo e refazer le en tres dias» (Evangelio de San Mateo, 224a, 61, pág. 69); «e tomo un panno de lino e cinxos lex (Hechos, 4, pág. 177); «e el uuestro gozo non uos le toldra ninguno» (Ibidem, 22, pág. 182); «Los caualleros, quand esto oyeron, cortaron las cuerdas del batel e dexaron le ir» (Ibidem, 32, pág. 243); «E por esta fuerça que dixiemos, le llaman iuego forçado. Mas por que algunos cuentan que las donzellas Le fallaron primero en la tierra de vltra mar... (Libro de açedrex, 25, pág. 26); «...e fincavan tres pora deffuera pora baratar el iuego e pora mannarle» (Ibidem, 25, pág. 26); «Qual pleyto tu quisieres / nos tal te le fagamos» (Apolonio, 89, pág. 11); «Este dado que yo do adon Rodrigo, dogele todo quito e libre despues de mios dias" (Documentos lingüisticos de España, 1243, Cuenca, 320, pág. 429); «...vendo auos Johan Esteuen... vn lagar que yo he... Evendo vos te conel ssobrado que hy he...» (Ibidem, 1361, Toledo, 297, pág. 403); «e este pedazo fue de Martin de Burgos... e por estos linderos es conoscido este pedazo de tierra calua. Todo uos le uendemos con entradas e con exidas... $\mathrm{E}$ nos uos somos fiadores e redradores de todos los omnes del mundo que uos le quieran demandar o contrallar... de manera que redremos e uos le fagamos sano» (Ibidem, 1263, Andalucía, 348, pág. 463) 104.

Lo primero que constatamos es el hecho de que todos los casos de leísmo de cosa son casos de singular. Efectivamente, el plural no registra, en los textos estudiados, ningún caso de leísmo de cosa. Ya ha señalado Lapesa que "el plural les como acusativo de cosa siempre ha sido excepcional en el lenguaje escrito ${ }^{105}$. Esto nos indica que la contienda con la categoría del neutro es la que ha originado la confusión

103 Agradezco a D. Rafael Lapesa la reconstrucción de este verso, al tiempo que me sumo a ella.

104 Nos parece muy raro que estos tres ejemplos de leísmo de cosa que encontramos en Andalucía, región que no se caracteriza hoy por el empleo de le para objeto directo de cosa (así como tampoco para el de persona), aparezcan precisamente en el mismo documento. El notario, según especifica el documento, era «don Uicent, fijo de don Lorenz", probablemente franco o hijo de franco, por el don y el Lorenz. El documento es de 1263, 27 ańos sólo después de la reconquista de Córdoba, donde está otorgado. No es probable que el notario hubiera nacido en Córdoba; su padre, desde luego, no.

105 Cfr. Rafael Lapesa, ob. cit., pág. 544. 
en este fenómeno ${ }^{106}$. Por otra parte, los textos en los que hemos encontrado casos de leísmo de cosa (Fazienda de Ultramar, Biblia, Libro de açedrex, Apolonio y documentos de mediados del siglo XIII) parecen indicar que existió un momento en el que la tendencia de la lengua por unificar las categorías de persona y cosa en la forma le, como portadora de la categoría de masculino, en tanto que lo se reservaba para el neutro, fue especialmente fuerte y coincide con el de máximo auge de leísmo personal.

\subsection{LAfSMO.}

En nuestros textos hemos encontrado algunos ejemplos de laísmo, aunque pocos, y no muy claros todos ellos:

«E si los fallares en signos fixos, di que la manceba es uirgen e linpia e salua de todo aleue e de quanto la sospecharon» (Libro conplido, 7, pág. 79) 107; «Quando fueren la Luna e Venus en alguno se los angulos e las catare Jupiter catamiento de amor, ... (Ibidem, 13, pág. 228) 108; abien mas de las iii. partes / la cercaua la mar» [a la ciudad] (Alexandre «O», 1092, pág. 195) 109; «bien mas de las tres partes / çercauala la mar* [a la ciudad] (Alexandre «P», 1092, pág. 194) 110; «Despues luego que la Diomedes tomo por rrienda, luego la començo a dezir: «por Dios, señora mia, ... (Historia Troyana, 17, pág. 149) 111; «De la tierra la leuantó, la santa paz la saludó» (Santa María Egipciaca, v. 1258) 112.

106 La Primera Crónica General puede resultarnos muy reveladora en este caso, pues, precisamente en aquellos fragmentos en los que apenas hay lo para objeto directo de persona masculino, es donde se registran más casos de le para objeto directo de cosa, lo que confirma la idea de que el leísmo de cosa obedece a una tendencia de la lengua por unificar las categorías de persona y cosa en la forma le, como portadora de la categoría de masculino, en tanto que lo se reserva para el neutro. Cfr. nuestro artículo «Sobre pronombres afijos en español antiguo. Interferencia de las categorias persona-cosan, Neuphilologische Mitteilungen, Helsinki, 1979, págs. 1-6.

107 Es un uso transitivo o, en todo caso, un la implemento, en lugar de suplemento, en la terminologia de Alarcos.

108 Creemos que este ejemplo debe entenderse no tanto como herencia de la construcción latina de acusativo interno, sino más bien como un caso de paranomasia que reproduce el giro árabe, tal como ha advertido Alvaro Galmés DE FuENTES, en su artículo «Interés en el orden lingüístico de la Literatura española aljamiado-morisca», $X$ Congrès Internacional de Linguistique et Philologie Romanes, Estrasburgo, 1962, págs. 527-546.

109 Puede interpretarse como aditamento, históricamente resto de ablativo de lugar en expresión circunstancial. Agradezco esta observación a Francisco Marcos.

110 Cfr. nota anterior.

III Se trata de un la regido por dezir, como complemento de persona, y por Dios como acusativo de cosa, es decir, podría interpretarse como doble acusativo, porque dezir equivale, semánticamente, a rogar, en este ejemplo.

112 Podría entenderse como un la objeto directo de la amalgama saludar la santa paz, 'besar'. Cfr. infra, nota 121. 
Ninguno de los ejemplos que recogemos aquí había sido señalado con anterioridad; los casos que se habían apuntado hasta ahora ofrecían carácter dudoso, de ahí que no se considerasen fidedignos los ejemplos anteriores al siglo XIV ${ }^{113}$. Los ejemplos que nosotros aportamos no son, tampoco, casos claros de laísmo, pero creemos que, de todos modos, pudieron favorecer su aparición.

\subsection{LEISMO DE PERSONA O COSA FEMENINA.}

La mayoría de le, les, que encontramos para representar un objeto directo femenino, van referidos a antecedente de persona, o bien a cosa femenina personificada o individuada por nombre propio. Los ejemplos que registramos en las obras de Berceo corresponden, todos ellos, a dativos etimológicos:

quisieron acorrelli [al alma] (Milagros, 274, pág. 103); «acorrioli a Burgos» (San Millán, 390, pág. 143; «...ca parçir non li quiso» [a Pancorbo] (Ibidem, 391, pág. 144).

También es un dativo etimológico éste que encontramos en el Libro de Alexandre (manuscrito $\propto O »)$ : "obedecer $l e$ an todos» [a ella] (2637, pág. 445). El resto de los ejemplos no corresponden ya a dativos etimológicos, sino a la confusión de formas (similar a la ocurrida en el leísmo personal masculino), si bien en el caso del leísmo femenino tal confusión es mucho menor, lo que se hace patente en el escaso número de ejemplos registrados. Los ejemplos concretos son:

*...no les podien foyr» [a las moscas] (Alexandre «O», 2173, pág. 377); «apedrearonle a tuerto [a ella] (Fazienda, pág. 109); «Commo non eran las cosas que pudiessen colpar / nin les podien foyr... [a las moscas] (Alexandre «P», 2173).

Los casos de antecedente femenino de cosa, que no esté personificada ni individuada, son los que siguen:

«después por la grant pudor que salyo del e non le podie sofrir, el mismo se mato con i. guchiello» (Fazienda, pág. 202); «Mando encara que qual quiere que bestia o qual quiere otra cosa trobare en la uilla et aquel dia aquella cosa non la fiziere pregonar e le trasnochare en su poder $e$ prouado' 1 fuere, peche la dupplada, assi como de furto (Fuero de Teruel, pág. 368); «nin les podian tornar» [estas cosas] (Alexandre «P», 2174, pág. 376); «a Dios sus derechuras todas les le rendemos» (Ibidem, 1934,

113 Cfr. Rafazl LAPESA, ob. cit., págs. 544 y 555. 
pág. 336) 114; «Non podie con el duelo las lagremas toller / yuales a menudo con el manto toller (Ibidem, 1776, pág. 310); *...mando le que preguntasse» [a ella] (Libro de Apolonio, 504, pág. 59).

Este último ejemplo parece ser que es adición del copista a una forma apocopada del manuscrito original ${ }^{115}$. Vemos, pues, que el leísmo referido a antecedente femenino tenía, en los primeros siglos de la lengua, poca extensión, sobre todo si lo comparamos con el leísmo referido a persona masculina. En cualquier caso, alguna tuvo, lo que nos muestra, una vez más, que existió desde muy pronto la tendencia a que le, les representaran la categoría de persona, englobando masculino y femenino. Pero el femenino opuso resistencia a ello, en tanto que el masculino se mostró absolutamente permeable a la invasión de le, les (sobre todo en singular) para objeto directo, permeabilidad que se hace patente desde los primeros tiempos de la lengua.

\subsection{LOfSMO ANTIETIMOLÓGICO.}

Rafael Lapesa ha señalado que el uso de $l o$, los para dativo masculino, aparece antes y con más frecuencia en plural ${ }^{116}$. Esta afirmación encuentra plena conformidad en nuestros datos. Por otra parte, el número de casos que hemos encontrado es elevado, por lo que parece que el fenómeno no fue tan raro:

*De mi parte affirmo e establesco con mio regno que lo teman e lo ayan miedo al Dios de Daniel» (Fazienda de Ultramar, pág. 179) 117; «apparecios el Nuestro Sennor otra vegada alli e bendixol e dixolo: 'El Poderoso e el Abastado acrez e muchigua yent, e conpannas de gentes yxtran de ti e reyes saldran de tos lomos» (Ibidem, pág. 140) 118; «Seon no los quiso dar passada, sino a boca de espada» (Ibidem, pág. 88); «Agora

114 En este último caso debemos destacar la existencia de doble redundancia pronominal: les duplica a derechuras y le a Dios (que mantiene su forma le sin haber evolucionado a ge, se, por la colocación peculiar, pospuesta al pronombre referido al objeto de cosa, rasgo de aragonesismo, por otra parte) que ha podido favorecer el leísmo. El problema de la redundancia ha sido convenientemente estudiado por ANa M.* Barrengchea, y Teresa Orecchia, en ela duplicación de objetos directos e indirectos en el español hablado en Buenos Aires», RomPhil, XXIV, 1970-71, págs. 58-83, y por Francisco Marcos MartN, en Estudios sobre el pronombre, Madrid, Gredos, 1978.

115 Así lo estima Manuer Alvar, por razones métricas, en la edición crítica del Libro de Apolonio, II, pág. 187.

116 Cfr. RAPARi. Lapesa, «Sobre los orígenes», pág. 548.

117 Es claro que aquí se trata de un caso de atracción, como consecuencia del pronombre lo que precede.

118 Cfr. nota 111. 
vienen todo el parentesco que los de el otro fijo (Ibidem, pág. 141); «Todos los que eran en la encontrada ayudavanlos con sus manos e davanlos vasos de oro e de plata e bestias e ço que avian mester (Ibidem, pág. 97) 119; «Dixo Naas que los aseguraria por un convynient que los sacaria a cada uno los oios diestros» (Ibidem, pág. 105); «Por ond de luengas tierras, lo enbian bodiuos» (Santo Domingo, 352, pág. 43); «Frayres dixo los muero me» (Ibidem, 494, pág. 59); «certificandolos que non serie el dia del iuyzio en so tiempo dellos» (Epistolas, pág. 357); «...e la yente otrossi non lo aura miedo» (Libro conplido, 13, pág. 228); «E quando fuere la Luna e la fortuna caydas de pars fortune, significa que grant partida de su auer se perdera e se esparzera, e si con esto la infortunare Mars, significa que gelo tomaran forçado, dando-lo penas por el. (Ibidem, 27, páq. 151); «E quando catare Mars al Sol de alguna de sus dignidades, significa poder e fortaleza de la caualleria e que despreciaran a sus enemigos e tener-s'a a ellos grant treuencia e los otros auer-los-an grant miedo* (Ibidem, 37, pág. 100); «sepades que no los quiso luengos prazos dar» (Alexandre «0», 1394, pág. 239); «...el buscara los amigos e su amor, e auer-los- a menester» (Libro conplido, 54, pág. 255); «...mas auer-los-a menester (Ibidem, 20, pág. 246); «...para lo toller las armas» (Historia Troyana, 7, pág. 47); «...que lo abrio todos los pechos» (Ibidem, 23, página 73); «...ca estonçe non los podia ninguno oyr las razones que ellos auien entresy de su amor (Ibidem, 15, pág. 188); «Todos a Apolonio meiorar lo querien / los tuertos e los danyos que fecho le auien* (Apolonio, 264, pág. 31); «...mercet los començo a pedir» (Libro de la Infancia $y$ Muerte, v. 206); «...e dieronlo tres plaços aque troxiesse su muger» (Documentos lingüísticos de España, Murcia, 1272, 369, pág. 488); «...i de quanto les fallaron $\mathrm{i}$ les uendieron, $\mathrm{i}$ de aquello que les apedgaron $\mathrm{i}$ los misieron, i de aquello que no les apedgaron i no les misieron en ello... (Ibidem, Osma, 1212, 208, pág. 269); «...entrando les e quebrantandoles por fuerça los sus prioradgos e... feriendo los e maltrayendo los e desonrrando los e tomando los por fuerça el pan e el uino e la carne (Ibidem, Valladolid, 1351, 241, pág. 114) 120.

Cuervo explicaba muchos casos de loísmo a partir de una equivalencia existente entre un verbo de sentido general y un acusativo que lo determina, con un verbo transitivo ${ }^{121}$. De este modo, casos como «aver miedo», «aver mester», «dar penas», llevarían pronombre acusativo por considerarse equivalentes a los verbos transitivos «necesitar», «temer», «penar». Es posible que esto favoreciese, en alguna medida, el incremento del loísmo. En cualquier caso, ello no serviría para explicar la preferencia del loísmo a aparecer en plural. Según puede observarse en los ejemplos anteriores, los casos de loísmo son 14 en plural, frente a 8 en singular, $y$, además, la preferencia por el plural es más

119 Cfr. nota 117.

120 Cfr. nota 117.

121 Cfr. Rufino José Cuervo, «Los casos», pág. 238. 
acentuada en los textos más antiguos. Por otra parte, observamos que los textos que ofrecen casos de loísmo son los mismos que conservan lo, los como continuación (etimológica) de la construcción latina con doble acusativo. Tales textos son: la Fazienda de Ultramar, el manuscrito I-I-6 de la Biblia y el manuscrito «O» del Libro de Alexandre. Asimismo, también este último es uno de los dos textos que nos proporcionan ejemplos de sujetos de infinitivo $u$ oración subordinados que presentan forma de acusativo, pese a que el verbo subordinado lleve objeto directo. Por tanto, constatamos, nuevamente, la relación existente entre estos fenómenos, que representan la tendencia a concentrar en la forma los (no tanto en singular) la categoría de masculino, habiendo fundido la distinción casual, por una parte, y las de persona y cosa, por otra. Su preferencia por el plural se explica por la ausencia, en él, de la categoría gramatical del neutro. Sin embargo, vemos que no es tan raro el loísmo en singular, aunque sí menos frecuente. Tampoco creemos que el ló́smo medieval se concentre en textos de marcado carácter dialectal ${ }^{122}$. Ya hemos visto que aparecía en la Fazienda de Ultramar, la Biblia, el Libro de açedrex, que no pueden ser considerados, ni por su composición ni por su mano de copia (dado lo que hoy sabemos) textos dialectales. Sí hay un núcleo de ejemplos concentrados en torno a textos de carácter dialectal, pero creemos que ello puede entenderse como la constatación del fenómeno en áreas dialectales y no como algo exclusivo de ellas.

\section{8. «LE» POR «LO» NEUTRO ACUSATIVO.}

Rafael Lapesa ha señalado ya que es éste un fenómeno muy raro ${ }^{123}$. Nosotros hemos encontrado algunos ejemplos, muy pocos, que ofrecemos a continuación:

«Si uos yo dix las cosas terrenales e no le creedes, ¿cuemo creeredes las celestiales si uos las dixier?» (Hechos, 12, pág. 155) 124; «E desi fable sobre las questiones. $\mathrm{E}$ esto pus en tres partes. $\mathrm{E}$ despues fable en las

122 Esto ha sido apuntado por RAFABL LAPBSA en su citado artículo, pág. 547. Nosotros no hemos encontrado corroboración para ello en nuestros ejemplos, sino que, por el contrario, creemos que los textos medievales ofrecen casos de lósmo como un indicio más de la contienda de formas de acusativo y de dativo en todos los niveles, sin estar relegados a zonas dialectales o a usos que caractericen a un estrato lingüístico determinado.

123 Cfr. RAFARI LAPESA, ob. cit., pág. 548.

124 Puede que en este ejemplo haya que ver el resultado de un cruce de me con le, por pérdida momentánea de noción de hablante en primera persona, más que con 60 , aunque puede que el cruce sea de tres formas me $\times$ le $\times l o$. 
nacencias, e pus-le en dos partes. E despues fable en las reuolutiones de los annos de las nacencias, e pus-le en vna parte... $E$ despues fable en las reuolutiones de los annos del mundo, e pus-le en vna parte» (Libro conplido, 24-31, pág. 5) 123.

Rufino José Cuervo no admitía la posibilidad de que el lo neutro fuese sustituido por la forma le, y los casos que él registra los considera producto de las exigencias de la rima ${ }^{12}$. Otro tanto piensa Salvador Fernández Ramírez, dado que los ejemplos de los que disponíamos hasta ahora no eran muy claros ${ }^{17}$. No puede pensarse lo mismo en los ejemplos que nosotros hemos registrado; por una parte, son textos en prosa y no pueden ser atribuidos a exigencias de la rima; por otra, parecen muy claros, al menos los últimos. Notemos, además, que el Libro conplido comenzó a escribirse en 1254 y que el manuscrito I-I-6 de la Biblia se considera escrito hacia 1260; la proximidad cronológica de ambos textos resulta obvia y puede que no sea producto de la casualidad el hecho de que los únicos casos de le por lo neutro se encuentren en dos textos tan cercanos. Sea como fuere, registramos este raro fenómeno, raro pero existente.

\section{CONCLUSIONES}

Creemos que todo lo expuesto en las páginas precedentes nos permite llegar a las siguientes conclusiones:

1) El empleo de la forma apocopada $l^{\prime}$ para objeto directo personal masculino alcanza su máximo apogeo en los comienzos de la segunda mitad del siglo xIII. No la encontramos empleada para tal función en los textos más tempranos, pese a que la apócope, como hecho lingüistico general, tiene su momento cumbre a primeros del siglo xIIr. La Fazienda de Ultramar es el texto en el que encontramos, por primera vez, un incremento considerable en su uso, que se acrecentará en el manuscrito $\mathrm{E}_{6}$ de la Biblia Escurialense, en Poridat de Poridades y en las obras alfonsíes El Libro conplido en los judizios de las estrellas y el Libro de açedrex.

125 Podría suponerse que ha habido pérdida del sentido del antecedente, aunque, el hecho de que el le se repita por tres veces consecutivas, parece indicar que no se ha dado tal, a menos que se considere un caso de atracción, cosa poco probable, pues no se trata de tres le sucesivos, sino que cada uno de ellos corresponde a una nueva formulación de la idea neutra.

123 Cfr. Rufino José CulRvo, aLos casos», pág. 113.

127 Cfr. Salvador Fernandez Rautrez, Gramática, pág. 198.

LXI. - 11 
2) En este último texto, terminado en 1283 , hemos encontrado indicios a partir de un cierto momento del texto, que corresponde a la descripción de la jugada 94, de abandono de la apócope y restitución de las formas plenas. Este momento podría corresponder a aquel en que Alfonso $\mathrm{X}$ decide oponerse al uso de las formas apocopadas. De hecho, la Historia Troyana es un buen ejemplo del descenso experimentado por tales formas de apócope.

3) De este descenso parece beneficiarse tanto la forma lo como le, como lo demuestra el hecho de que el porcentaje de apócope que pierde el manuscrito del Libro de Apolonio respecto del original, se reparte equitativamente entre lo y le. Otro tanto sucede en el manuscrito « $\mathrm{P}$ * del Libro de Alexandre (más tardío) respecto del manuscrito «O». $\mathrm{Y}$, por último, la Historia Troyana, caracterizada por un uso menor de la apócope en relación a los textos anteriores, presenta una mayoritaria restitución de $l o$.

4) El momento en que los textos ofrecen mayores porcentajes de apócope, para la función de objeto directo masculino, coincide con un momento especialmente alto del leísmo personal en singular. Los textos que mayores porcentajes de apócope arrojan son, también, los que presentan porcentajes más elevados para le. A primera vista, cabría pensar que el empleo de $l$, tanto para la función de objeto directo como para la de indirecto, favoreciese la confusión; pero el hecho es que, después, se restituyen con preferencia las formas de acusativo. Por tanto, tal confusión, si la hubo, se dio en el mismo momento de coexistencia de la apócope, y no fue total. La diferenciación entre formas de acusativo y de dativo resistió lo suficiente (al menos de una forma mental) para que continuara siendo un hecho una vez pasado el momento de uso de apócope. Lo sucedido en Andalucía da buena fe de ello. Debemos tener en cuenta, por otra parte, que, emplear la forma apocopada $l$ ', debía resultar especialmente cómodo en una situación de conflicto entre le y Lo. No debemos olvidar que tal apócope fue la más duradera, tal vez por esta razón.

5) La evolución del leísmo personal, en los primeros siglos de la lengua, es un hecho que se documenta bien, por lo que se refiere al singular. Apenas hay ejemplos en los textos más antiguos. Los que encontramos en Berceo responden a usos latinos de verbos que se construían con dativo. La Fazienda de Ultramar es un texto clave: muestra un notable incremento en el porcentaje de $l e$, usado con verbos cuyos antecedentes latinos nada tienen que ver con usos de dativo. De cual- 
quier manera, tales verbos vacilan aún en la Fazienda entre el empleo de 10 o de le. En cambio, son ya pocos los verbos que vacilan en el manuscrito I-I-6 de la Biblia; han elegido, la mayor parte de ellos, una forma determinada, y esa forma es, casi siempre, le. El leísmo, en este momento, es intensísimo; tanto, que parece obedecer a una clara preferencia por el uso de le para objeto directo de persona masculino. La vacilación comenzada en la Fazienda de Ultramar se ha decidido ahora por la forma le. Pero, a partir de aquí, y como fenómeno paralelo al descenso de la apócope, vendrá la restitución de lo para tal función. De cualquier manera, el camino a la vacilación está ya abierto y las formas etimológicas no se restituirán totalmente, aunque el leísmo personal ofrecerá diferentes grados de extensión, ligados a la varia repartición geográfica.

6) Este leísmo de persona singular nos muestra la tendencia de la lengua a esbozar un paradigma le, la y lo para masculino, femenino y neutro, respectivamente. Esto se apoya en el hecho de que el leísmo es más frecuente en singular que en plural, donde no existe la categoría de neutro, $\mathrm{y}$, además, en que, en los textos donde hay más le para objeto directo masculino personal, es donde son más frecuentes los casos de leísmo de cosa. Esta tendencia fue especialmente importante a comienzos de la segunda mitad del siglo XIII. El paradigma resultante, le, la, lo, sería perfecta correspondencia de este / esta / esto, ese / esa / eso, aquel(le) / aquella / aquello, el(le) / ella / ello. De ahí que, en plural, las formas analógicas, o apoyadas por la analogía con estos paradigmas, serían los, las, guardando perfecta correspondencia con estos / estas, esos / esas, aquellos / aquellas, ellos / ellas.

7) Reflejo de eso último sería el hecho, constatado, de que el loísmo sea un fenómeno que aparece preferentemente en plural, que los casos de doble acusativo mantenido prefieran, asimismo, el plural, y que plurales sean todos los casos encontrados de sujeto de infinitivo u oración subordinada que, llevando el verbo subordinado objeto directo, presentan forma de acusativo. Así, pues, parece que, en los primeros siglos de la lengua, sobre todo en el siglo XIII, existió una fuerte tendencia a la creación de estos paradigmas, sin distinción de caso.

8) Pero el leísmo de cosa no alcanzó más que a textos en los que el leísmo de persona era especialmente abundante. Por otra parte, la aparición del laísmo no pasa de ser un tímido intento en el siglo xIII. Y, junto al loísmo, hemos encontrado la tendencia contraria: el uso de 
les para objeto directo, que fue ayudado por la sustitución del acusativo latino por el dativo en determinadas construcciones.

9) En tales construcciones, la «cronología de los textos» muestra que la sustitución más temprana se dio en los casos en que el objeto directo lleva un complemento predicativo referente a él, hecho que se documenta ya en el Liber Regum, texto sumamente conservador en el uso de los pronombres átonos de tercera persona. No tan temprana es la aparición del dativo en construcciones en las que el sujeto de infinitivo o de oración subordinada desempeña la función de objeto directo, pero está ya registrada desde la Fazienda de Ultramar. Por último, si bien encontramos aún en algunos textos el doble régimen acusativo del latín mantenido, la sustitución del acusativo personal por el dativo es la norma general en los textos.

10) Hemos visto, por otra parte, que el leísmo para antecedente femenino, ya sea de persona o de cosa, ofrece pocos casos, lo que nos indica que la oposición genérica estaba presente de una forma muy viva.

11) Algunos ejemplos hemos encontrado (pocos) de le por lo neutro acusativo. Es notable que este raro fenómeno se registre en El libro conplido y en el manuscrito I-I-6 de la Biblia, textos muy próximos cronológicamente.

Todo ello nos muestra cómo, desde los primeros tiempos de la lengua, el empleo de los pronombres átonos de tercera persona le, la, lo y sus plurales, ha sido enormemente conflictivo.

En nuestro trabajo encuentra corroboración lo que ya había sido señalado anteriormente por Salvador Fernández ${ }^{123}$ y por Rafael Lapesa ${ }^{129}$, a saber, que el fenómeno de mayor envergadura es el leísmo de persona, cuyo origen fue, sin duda, la perduración del dativo con una serie de verbos que lo regían en latín, y su contagio a otros, hasta llegar a invadir toda el área del objeto directo personal ${ }^{130}$. Lamentamos la escasez de trabajos acerca de otro fenómeno estrechamente relacionado con el objeto de nuestro estudio, como es la propagación de la preposición $a$ ante objeto directo. Recordemos que «en los dos fenómenos se manifiesta la misma forma linguística interior, que tiende a distinguir gramaticalmente las categorías de persona y de cosa» ${ }^{131}$. Es

128 Cfr. Salvador Fernandez Rantrez, «Un proceso linguístico en marcha*, en Presente y Futuro de la Lengua Española, 2, pág. 278.

129 Cfr. Rafari Lapasa, ob. cit., pág. 549.

130 Cfr. Ibidem, pág. 549.

131 Cfr. Ibidem, páz. 549. 
de esperar que nuevos estudios linguísticos, abordados con una metodología histórica, nos proporcionen los datos, tan necesarios, para llegar a comprender la compleja evolución de estos dos fenómenos que, aún hoy, y a cada paso, nos ofrecen ejemplos vivísimos de conflicto linguístico ${ }^{132}$.

\section{M." Teresa Echenioue Elizondo}

132 Ediciones utilizadas cuya mención puede ser necesaria para encontrar los pasajes que se citan: Alponso X, Libro de açedrex, dados e tablas, edición de Arnald Steiger, Romanica Helvetica, vol. 10, Ginebra-Zürich, 1941; Libro conplido en los judizios de las estrellas, edición de Gerold Hilty, Madrid, Real Academia Española, 1964; Auto de los Reyes Magos, edición de Ramón Menéndez Pidal, R. A. B. M., II, 1900, 3." época. GoNzALO DE Berceo, según ed. de Brian Dutton: El Duelo de la Virgen, Londres, Tamesis Books Ltd., 1975; Loores de Nuestra Señora, Londres, Tamesis Books Ltd., 1975; Milagros de Nuestra Señora, Londres, Tamesis Books Ltd., 1971; Vida de San Millán de la Cogolla, Londres Tamesis Books Ltd., 1967; Los Signos del Juicio Final, Londres, Tamesis Books Ltd., 1975; Vida de Santo Domingo de Silos, edición de Fray Alfonso de Andrés, O. S. B., Madrid, Padres Benedictinos, 1958. Biblia escurialense, El Evangelio de San Mateo según el manuscrito escurialense I.I.6. Texto, gramática y vocabulario, edición de Thomas Montgomery, anejo VII del Boletín de la Real Academia Española, Madrid, 1962; El Nuevo Testamento según el manuscrito I.I.6, desde el Evangelio de San Marcos hasta el Apocalipsis, edición de Thomas Montøomery y Spurgeon W. Baldwin, anejo XXII del Boletín de la Real Academia Española, Madrid, 1970. Diez Mandamientos, Los, edición de Morel Fatio, Romania, XVI, 18. Documentos Lingǘsticos de España. Reino de Castilla, edición de Ramón Menéndez Pidal, anejo LXXXIV de la RFE, C. S. I. C., Madrid, 1966. Duelo de la Virgen, v. BERCEo. Elena y María, edición de Ramón Menéndez Pidal, RFE, I, 1914, págs. 52-96. Fazienda de Ultramar, La, edición de Moshé Lazar, «Acta Salmanticensia», Salamanca, 1965. Fuero de Alba de Tormes, edición de Américo Castro y Federico de Onís, en Fueros leoneses de Zamora, Salamanca, Ledesma y Alba de Tormes, Madrid, Centro de Estudios Históricos, 1916. Fuero de Madrid, ed. Ayuntamiento de Madrid, Madrid, Archivo de Villa, 1963. Fuero de Teruel, edición de Max Gorosch, «Leges hispanicae medii aevii», Estocolmo, 1950. Fuero de Valfermoso de las Monjas (hemos utilizado una transcripción que amablemente nos cedió D. Rafael Lapesa, corregida de su propia mano). Historia Troyana, edición de Ramón Menéndez Pidal, anejo XVIII de la RFE, Madrid, 1934. Liber Regum, edición de Louis Cooper, Zaragoza, Institución «Fernando el Católico», 1960. Libro conplido en los judizios de las estrellas, v. Alfonso X. Libro de açedrex, dados e tablas, v. Alponso X. Libro de Alexandre, edición de R. Jr. Willis, Nueva York, Elliott Monograph, 1965. Libro de Apolonio, edición de Manuel Alvar, Madrid, Fundación Juan March y editorial Castalia, 1976, y edición de Charles Carroll Marden, reimpresión de Nueva York, Klaus Reprint Corporation, 1965. Libro de la Infancia y Muerte de Jesús (Libre dels tres Reys d'Orient), edición de Manuel Alvar, "Clásicos Hispánicos», C. S. I. C., Madrid, 1965. Loores de Nuestra Señora, v. BERCEo. Milagros de Nuestra Señora, v. Berceo. Planto iAy Jerusalén!, edición de Manuel Alvar, en Antigua poesía española lírica y narrativa, Méjico, Porrúa, 1970. Poridat de las Poridades, edición de Lloyd A. Kasten, Madrid, 1957. Razón de Amor, edición de Ramón Menéndez Pidal, en Revue Hispanique, XIII, 1905. Roncesvalles, edición de Ramón Menéndez Pidal, en RFE, tomo IV, abril-junio, 1917. Signos del Juicio Final, v. Berceo. Vida de Santa María Egipciaca, edición de Manuel Alvar, "Clásicos Hispánicos», C. S. I. C., Madrid, 1970. Vida de Santo Domingo de Silos, v. Berceo. Vida de San Millán de la Cogolla, v. Berceo. 